\title{
Paleoclimate and paleoecology of the Upper Oligocene Tehuacán Formation, Puebla State, Mexico, as determined from wood anatomical characters
}

\author{
Marco A. Rubalcava-Knoth and Sergio R.S. Cevallos-Ferriz
}

\begin{abstract}
Climatic conditions that prevailed during the deposition time of the Tehuacán Formation, Mexico (upper Oligocene) are proposed based on a previous model using wood anatomical characters. Different paleoclimatic variables were calculated, and the anatomical characteristics of the Tehuacán Formation paleoflora were compared with the characteristics of other extant and fossil plant communities to infer water conductive capacities of the Tehuacán Fm. plants. The paleoclimatic inference suggests that the environmental conditions under which the fossilized plants of the Tehuacán Fm. grew were seasonally warm and humid. Statistical analysis and the presence of growth rings in some woods suggest that the paleoflora of the Tehuacán Fm. were similar to extant tropical communities such as tropical semi-deciduous forests and the tropical deciduous forests, most probably representing a transitional community: containing plants that were efficient in transporting water like those in the tropical wet forests, but with phenological adaptations typical of drier tropical forests.
\end{abstract}

Marco A. Rubalcava-Knoth. Posgrado en Ciencias Biológicas, Instituto de Geología, UNAM; Ciudad Universitaria, Circuito de la Investigación Científica, Copilco El Alto, Coyoacán; 04510 Mexico D.F., Mexico.paleoplantas@gmail.com

Sergio R.S. Cevallos-Ferriz. Departamento de Paleontología, Instituto de Geología, UNAM; Ciudad Universitaria, Circuito de la Investigación Científica, Copilco El Alto, Coyoacán; 04510 Mexico D.F., Mexico.scrscfpb@unam.mx

Keywords: ancient vegetation; paleobotany; Cenozoic; fossil wood; paleoclimate, Mexico

Submission: 25 October 2020. Acceptance: 23 April 2021.

Rubalcava-Knoth, Marco A. and Cevallos-Ferriz, Sergio R.S. 2021. Paleoclimate and paleoecology of the Upper Oligocene Tehuacán Formation, Puebla State, Mexico, as determined from wood anatomical characters. Palaeontologia Electronica, 24(2):a17. https:// doi.org/10.26879/1136

palaeo-electronica.org/content/2021/3347-paleoclimate-in-tehuaca-formation

Copyright: May 2021 Paleontological Society.

This is an open access article distributed under the terms of Attribution-NonCommercial-ShareAlike 4.0 International (CC BY-NC-SA 4.0), which permits users to copy and redistribute the material in any medium or format, provided it is not used for commercial purposes and the original author and source are credited, with indications if any changes are made.

creativecommons.org/licenses/by-nc-sa/4.0/ 


\section{INTRODUCTION}

Understanding the interactions between living organisms and the physical environment in terrestrial ecosystems has benefited from the study of the influence of climate on plants (Turner et al., 1999; Smith et al., 2013). These observations indicate that morphological and anatomical characteristics of certain plant organs, such as secondary xylem (diameter of the vessel elements), maintain a close relationship with climatic conditions in which plants develop (e.g., Wheeler and Baas, 1993; Calrquist, 1997; Weimann et al., 1998).

One of the plant structures in which expression is strongly modeled by the climate is the secondary xylem that has been widely studied and used for paleoclimatic determination (e.g., Chaloner and Creber, 1990; Wheeler and Baas, 1991; Woodcock and Ignas, 1994; Wiemann et al., 1998; 1999; Poole, 2000; Martínez-Cabrera and Cevallos-Ferriz, 2008; Martínez-Cabrera and EstradaRuíz, 2018). Weimann et al. (1998) developed the first statistical model that allowed predicting a group of climatic variables based on fossil wood. Following the Weimann methodology, MartínezCabrera and Cevallos-Ferriz (2008) proposed an alternative model that they applied for paleoclimatic interpretations of Cenozoic Mexican paleofloras based on anatomical wood characters.

Although paleoclimatic and paleobotanical studies of the Oligocene in Mexico are few, they suggest that in the north and center of the country the predominant climatic conditions were subhumid tropical with some degree of seasonality, and that the vegetation was similar to dry tropical forests, chaparrals, or savannas (Cevallos-Ferriz and Calvillo-Canadell, 2012; Pérez-García et al., 2012; Ramírez-Arriaga et al., 2014). The climatic conditions that prevailed in Mexico during the Oligocene have been explained as the result of a long process in which seasonal climates were slowly replacing more stable and humid tropical ones (Graham, 1999; Ferrari et al., 2000; Gómez-Tuena et al., 2007; Cevallos-Ferriz and Calvillo-Canadell, 2012).

The best studied paleofloras for the Oligocene of Mexico correspond to those contained in the Coatzingo and Cuayuca Formations in the state of Puebla (Central Mexico), which have been interpreted as vegetation types reminiscent of a dry tropical forests or chaparral that grew under a seasonal subhumid tropical climate (Magallón-Puebla and RS Cevallos-Ferriz, 1993; Ramírez and Cevallos-Ferríz, 2000; Velasco de León and CevallosFerriz, 2000; Beraldi-Campesi et al., 2006;
Ramirez-Arriaga et al., 2008; Méndez-Cárdenas et al., 2014). Therefore, the climatic conditions that existed during the upper Oligocene in the Tehuacán Formation, Puebla (geographically close to the Coatzingo and Cuayuca Formations), are calculated based on wood anatomical characters and add information to understand the general climatic conditions that prevailed at that time in the central region of Mexico (Tehuacán Valley). In addition, information is provided about some paleoecological aspects of the paleoflora and some physiological aspects of the plants are explained.

\section{MATERIAL AND METHODS}

\section{Tehuacán Formation}

The strata of the Tehuacán Formation outcrop in the southeast of the state of Puebla (Mexico), in the Tehuacán Valley (Figure 1), and represent a lacustrine sedimentary sequence (upper Oligocene- middle Miocene) with a thickness that varies from 700 to $800 \mathrm{~m}$. The basal portion of the sedimentary sequence is composed of calcareous rocks, sandstones and siltstones. Towards the top are shales and gypsum predominate with interspersed tuffs (Dávalos-Alvarez et al., 2007; Ramírez-Arriaga et al., 2014). According to lithological data, the sedimentary environment is interpreted as a continental sequence with lake facies that were deposited in endorheic basins. The lakes that originated these facies had a variable water

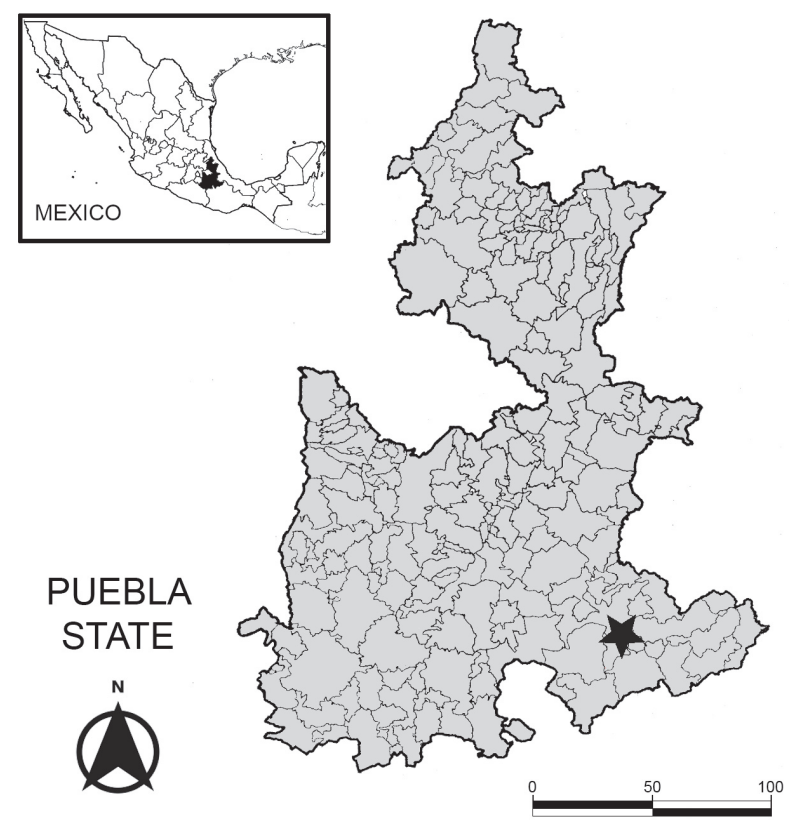

FIGURE 1. Geographical location of the Tehuacán Fm. in the state of Puebla, Mexico. 
depth subject to floods and droughts (DávalosAlvarez et al., 2007). The age of the base of the Tehuacán Fm. has been estimated to be approximately 27.1 million years (K-Ar) (upper Oligocene), while for the upper part an age of 16.4-15.6 million years (K-Ar) (middle Miocene) has been proposed (Dávalos-Alvarez et al., 2007; Ramirez-Arriaga et al., 2014).

The fossil woods studied were collected near the town of San Juan Atzingo in the municipality of San Gabriel Chilac, in the Tehuacán Valley, Puebla (Figure 1), in a sequence that represents the base of the Tehuacán Formation (upper Oligocene).

\section{Fossil Material}

The fossil woods were laminated following the standard technique used for permineralized fossil material (Haas and Rowe, 1999). Thin sections were obtained in the transverse (TS), tangential (TLS), and radial (RLS) planes (Jud et al., 2017). Among the studied samples, 20 well-preserved morphotypes were recognized for which anatomical characters were easily observed (they are identified as Morpho 1 to Morpho 20). All of the morphotypes are deposited in the Colección Nacional de Paleontología, Instituto de Geología, UNAM (Appendix 1). Figure 2 illustrates selected transverse, tangential, and radial sections of the wood material that exemplify the anatomical variation of different morphotypes belonging to the paleoflora under study.

In order for the wood anatomy of a paleoflora to adequately represent climatic parameters, Weimann et al. (1998; 1999) and latter MartínezCabrera and Cevallos Ferriz (2008) suggest that the calculated data (climatic variables) should include mean values of the characters of at least 23 different morphotypes. Since only 20 morphotypes were recognized through our review, other morphotypes from the same locality and described by Sainz-Resendiz (2008) were added to our study (identified as S.R. Morpho 1 to S.R. Morpho 8; Appendix 1).

In each of the 20 morphotypes, 34 wood anatomy characters strongly related to climatic variables were observed [(Martínez-Cabrera and Cevallos-Ferriz, 2008) (Table 1)]. The values of each morphotype for each character represent the proportion value (for qualitative traits) and the mean (for quantitative traits) of 25 different observations (Appendix 1). The criteria to encode each of the characters was the same one used by Martínez-Cabrera and Cevallos-Ferriz (2008) and shown in Table 1 for each character. For the eight morphotypes studied by Sainz-Reséndiz (2008), the information of the mean and proportion were extracted directly from her writing since the measurements include most of the 34 characters strongly related to some climatic variable (Appen$\operatorname{dix} 1$ ).

Once the proportion and mean values of the 34 characters strongly related to climatic variables were obtained for each of the 20 morphotypes identified in this study and the eight morphotypes studied by Sainz-Reséndiz (2008), the average anatomical data (for each character) of the Tehuacán Fm. paleoflora were calculated (Appendix 2).

In addition to the aforementioned data, measurements of nine tracheal characteristics of the paleoflora of the $\mathrm{Fm}$. Tehuacán were made: vessel per square millimeter $\left(\mathrm{Vmm}^{2}\right)$, mean vessel diameter (VD), mean vessel length (VL), mean vessel grouping (VG), mean number of bars per perforation plate (BAR), tracheid proportion ( $T$ ), proportion of helical sculpture (latewood + earlywood proportion), growth rings (GR), and mesomorphy index (Meso) (Carlquist and Hoekman, 1985). These tracheal characteristics were coded following the guidelines of Carlquist and Hoekman, (1985) (Table 2) in order to compare these tracheal characteristics of the Tehuacán Fm. paleoflora with those of other current communities and fossils (for more detail see section "tracheal elements comparison").

\section{Climate Inferences}

The paleoclimatic conditions of the paleoflora of the Tehuacán Formation were calculated based on the model proposed by Martínez Cabrera and Cevallos-Ferriz, (2008). They provided equations for inferring distinct climatic variables: MAT (mean annual temperature), MART (mean annual range of temperature), MAPE (mean annual potential evaporation), MARPE (mean annual range of potential evaporation), Max PE (maximum potential evaporation), and Min PE (minimum potential evaporation) (Table 3), based on particular anatomical features present in the community. Calculation of paleoclimatic variables of the Tehuacán Fm. used the average anatomical data in Appendix 2 (Martínez-Cabrera and Cevallos-Ferriz, 2008).

In this work, other climatic variables were not calculated (e.g., mean annual precipitation, length of dry season) since the results of MartínezCabrera and Cevallos-Ferriz (2008) show little statistical significance for these, suggesting that the characters seem to be related with other climatic variables like temperature. 

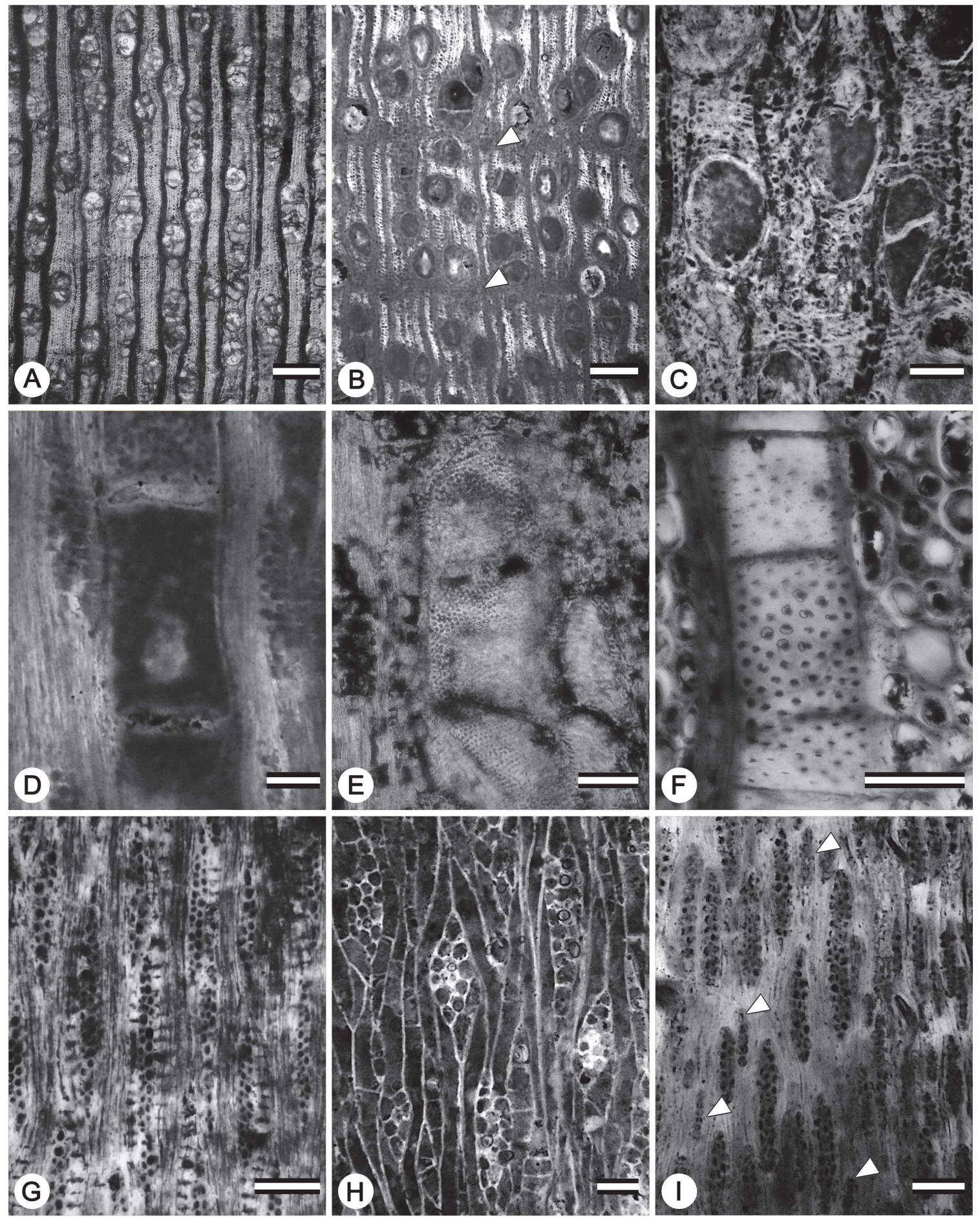

FIGURE 2. Morpho-anatomic diversity of the paleoflora of the Tehuacán Fm. - A: Morphotype 2. Diffuse porosity with solitary and aggregates of vessels (2-3) with tylosis (TS). - B: Morphotype 16. Diffuse porosity with solitary and aggregate vessels (2), vasicentric and banded parenchyma bands (white arrows) (TS). - C: Morphotype 6. Detail of solitary and aggregate vessel elements with dark contents, thick walls and parenchyma bands (TS). - D: Morphotype 12. Long and wide vessel elements and multiseriate rays (RSL). - E: Morphotype 1. Vessel elements with alternate intervascular pits (RSL). - F: Morphotype 4. Short and wide vessel elements with alternating intervascular pits (TSL). G: Morphotype 3. Biseriate rays (TSL). -H: Morphotype 19. Multiseriate rays and abundant axial parenchyma (TSL). I: Morphotype 14. Rays mostly biseriate, some uniseriate (white arrows). Scale bar: $250 \mu \mathrm{m}$ in A, B; $100 \mu \mathrm{m}$ in C, D, E, $\mathrm{G}, \mathrm{H}, \mathrm{l} ; 50 \mu \mathrm{m}$ in $\mathrm{F}$. 
TABLE 1. Wood anatomical characters related to climatic variables and codification criteria for each one (MartínezCabrera et al., 2008).

\begin{tabular}{|c|c|}
\hline Character & Codification criteria \\
\hline 1.- Growth rings & Present (1)/Absent (0) \\
\hline 2.- Vessel grouping & Vessel clusters $(2,3,>4)$ proportion \\
\hline 3.- Vessel frequency & Number of vessels per square millimeter \\
\hline 4.- Vessel diameter & Diameter in $\mu \mathrm{m}$ \\
\hline 5.- Vessel wall thickness & Thickeness wall in $\mu \mathrm{m}$ \\
\hline 6.- Helical sculpture & Present (1)/Absent (0) \\
\hline 7.- Intervascular pit apertura diameter & Diameter in $\mu \mathrm{m}$ \\
\hline 8.- Alternate intervessel pits & Present (1)/Absent (0) \\
\hline 9-. Opposite intervessel pits & Present (1)/Absent (0) \\
\hline 10.- Scalariform intervessel pits & Present (1)/Absent (0) \\
\hline 11.- Simple perforation plates & Present (1)/Absent (0) \\
\hline 12.- Scalariform perforation plates & Present (1)/Absent (0) \\
\hline 13.- Fibre wall thickness $(\mu \mathrm{m})$ & Thickeness wall in $\mu \mathrm{m}$ \\
\hline 14.- Fibre lumen diameter $(\mu \mathrm{m})$ & Lumen diameter $(\mu \mathrm{m})$ \\
\hline 15.- Tracheids & Present (1)/Absent (0) \\
\hline 16.- Fibrotracheids & Present (1)/Absent (0) \\
\hline 17.- Libriform fibres & Present (1)/Absent (0) \\
\hline 18.- Parechyma diffuse in aggregates & Present (1)/Absent (0) \\
\hline 19.- Vasicentric parenchyma & Present (1)/Absent (0) \\
\hline 20.- Aliform parenchyma & Present (1)/Absent (0) \\
\hline 21.- Apotracheal parenchyma bands & Present (1)/Absent (0) \\
\hline 22.- Concentric parenchyma bands & Present (1)/Absent (0) \\
\hline 23.- Marginal parenchyma & Present (1)/Absent (0) \\
\hline 24.- Height of uniseriate ray & Height in $\mu \mathrm{m}$ \\
\hline 25.- Height of uniseriate ray & Number of cells \\
\hline 26.- Percentage of uniseriate rays & Percentage of uniseriate rays \\
\hline 27.- Exclusively uniseriate rays & Present (1)/Absent (0) \\
\hline 28.- Width of multiseriate ray & Width in $\mu \mathrm{m}$ \\
\hline 29.- Width of multiseriate ray & Number of cells \\
\hline 30.- Length of uniseriate extensions $(\mu \mathrm{m})$ & Length in $\mu \mathrm{m}$ \\
\hline $\begin{array}{l}\text { 31.- Length of uniseriate extensions ( } n^{\circ} \\
\text { cells) }\end{array}$ & Number of cells \\
\hline 32.- Storied structure & Present (1)/Absent (0) \\
\hline 33.- Heterocellular rays & Present (1)/Absent $(0)$ \\
\hline 34.- Homocellular rays & Present (1)/Absent $(0)$ \\
\hline
\end{tabular}

\section{Wood Anatomy Comparison}

The anatomy of the wood of the paleoflora of the Tehuacán Fm. was compared with that of plants of other communities using two different data sets (Martínez-Cabrera and Cevallos-Ferriz, 2008). The first compared the general physiognomic characteristics (the 34 anatomical characters strongly related to the climate) of the paleoflora with that of other mesic communities (communities compiled from Castañeda-Posadas, 2007 and Martínez-Cabrera and Cevallos-Ferriz, 2008). The second compared the tracheal elements of the fossil paleoflora (nine tracheal characteristics) with those of mesic communities (communities compiled from Castañeda-Posadas, 2007 and Martínez-Cabrera and Cevallos-Ferriz, 2008) and Southern California ecological categories (Carlquist and Hoekman, 1985). These obser- 
TABLE 2. Tracheal characteristics and codification criteria for each one (Carlquist and Hoekman, 1985).

\begin{tabular}{ll}
\hline \multicolumn{1}{c}{ Character } & \multicolumn{1}{c}{ Codification criteria } \\
\hline 1.- Vessels per square millimeter $\left(\mathrm{Vmm}^{2}\right)$ & Number of vessels per square millimeter \\
2.- Mean vessel diameter $(\mathrm{VD})$ & Diameter in $\mu \mathrm{m}$ \\
3.- Mean vessel lenght $(\mathrm{VL})$ & Length in $\mu \mathrm{m}$ \\
4.- Mean vessel grouping $(\mathrm{VG})$ & Vessel clusters $(2,3,>4)$ proportion \\
5.- Mean number of bars per perforation plate (BAR) & Number of bars \\
6.- Tracheid proportion (T) & Present (1)/Absent $(0)$ \\
7.- Proportion of helical sculpture (latewood+early & Present (1)/Absent $(0)$ \\
wood proportions) (SE) & \\
8.- Growth rings (GR) & Present (1)/Absent $(0)$ \\
9-. Mesomorphy index (Meso) & Vessel diameter $\div$ Number of vessels per square millimeter \\
\hline
\end{tabular}

vations were made under the assumption that "plants that grow under similar environmental conditions will have similar anatomical characteristics" (Martínez-Cabrera and Cevallos-Ferriz, 2008).

Physiognomic comparison. Physiognomic comparison of the paleoflora of the Tehuacán Formation with other extant and fossil plant communities is based on a data matrix (Appendix 3) that includes the average anatomical data of the paleoflora of the Tehuacán Fm., data based on MartínezCabrera and Cevallos-Ferriz (2008) that includes another Mexican paleoflora (El Cien), three Mexican extant communities: tropical deciduous forest (Chamela, Jalisco), Los Tuxltas (tropical rain forest in Veracruz), Mountain Forest (Ocuilán, Mexico), and three South American extant wet tropical communities: Porto Vehlo and Manaus (Brazil), and Tafelberg (Suriname). Finally, also included were the data compiled by Castañeda-Posadas (2007) from two Mexican communities: a semi-deciduous tropical forest (Champeche) and a xeric shrubland (Puebla). Like the anatomical data of the Tehuacán Fm., this matrix (Appendix 3) includes the average anatomical data for each of the 34 characters related to climatic variables of each plant type of the extant communities and paleoflora (MartínezCabrera and Cevallos-Ferriz, 2008). The statistical methods used to make the comparison were cluster analysis, performed using Euclidean distances (ED) applied in the hierarchical agglomerative cluster analysis of the Average Taxonomic Distance (ATD) type and Principal Components Analysis (PCA). The computer program used in this study was $R$ ( $R$ core project, 3.6.1) with the statistical packages ggplot2, ggdendro, ade4, factoextra, and magrittr.

Tracheal elements comparison. Similarity of tracheal characteristics of the paleoflora of the Tehu-

TABLE 3. Equations obtained by Martínez-Cabrera et al., (2008) for the variables MAT (mean annual temperature), MART (mean annual range of temperature), MAPE (mean annual potential evaporation), MARPE (mean annual range of potential evaporation), Max PE (maximum potential evaporation) and Min PE (Minimum potential evaporation) and climatic estimations for Tehuacán Fm.

\begin{tabular}{|c|c|c|c|}
\hline $\begin{array}{l}\text { Climatic } \\
\text { Variable }\end{array}$ & & Equation & Estimation \\
\hline \multirow[t]{3}{*}{ MAT } & 1 & $\begin{array}{l}27-0.42 \text { (pit diameter) }+2.94 \text { (apotracheal bands) - } 33.88 \text { (scalariform } \\
\text { pits) }\end{array}$ & $24.9^{\circ} \mathrm{C}$ \\
\hline & 2 & 29.9 - 32.85 (scalariform pits) - 0.75 (pit diameter) & $25.2^{\circ} \mathrm{C}$ \\
\hline & 3 & $23.53-31.33$ (scalariform pits) + 6.11 (apotracheal bands) & $24.6^{\circ} \mathrm{C}$ \\
\hline \multirow[t]{2}{*}{ MART } & 4 & $\begin{array}{l}2.026+0.907 \text { (pit diameter) }+1.37 \text { (apotracheal bands) }-0.867 \text { (fiber } \\
\text { wall) }\end{array}$ & $5.5^{\circ} \mathrm{C}$ \\
\hline & 5 & $2.91+.889$ (pit diameter) -1.01 (fiber wall) & $4.6^{\circ} \mathrm{C}$ \\
\hline MAPE & 6 & $-1473.5+1228($ vessel grouping $)+\left(\right.$ vessel $\left./ \mathrm{mm}^{2}\right)$ & $936.7 \mathrm{~mm}$ \\
\hline MARPE & 7 & $-134.4+121.86$ (vessel grouping) & $78.4 \mathrm{~mm}$ \\
\hline Max PE & 8 & $144.467+2.58\left(\right.$ vessel $\left./ \mathrm{mm}^{2}\right)-0.25$ (cells height of uniseriate rays) & $169.9 \mathrm{~mm}$ \\
\hline Min PE & 9 & $15.849+2.54\left(\right.$ vessel $\left./ \mathrm{mm}^{2}\right)$ & $42.51 \mathrm{~mm}$ \\
\hline
\end{tabular}


TABLE 4. Data for the nine tracheal characteristics. * Carlquist y Hoekman, 1985, ** Martínez-Cabrera et al., 2008, *** Castañeda-Posadas, 2007. Vmm² = vessels per square millimeter; VD= mean vessel diameter $(\mu \mathrm{m})$; $\mathrm{VL}=\mathrm{mean}$ vessel length $(\mu \mathrm{m}) ; \mathrm{VG}=$ mean vessel grouping; $\mathrm{BAR}=$ mean number of bars per perforation plate; $\mathrm{T}=$ tracheid proportion; $\mathrm{SE}=$ proportion of helical sculpture (latewood + early wood proportions); GR= growing rings; MESO= mesomorphy index.

\begin{tabular}{|c|c|c|c|c|c|c|c|c|c|}
\hline $\begin{array}{c}\text { Community / ecological } \\
\text { category }\end{array}$ & $\mathrm{Vmm}^{2}$ & VD & VL & VG & BAR & $\mathbf{T}$ & SE & GR & MESO \\
\hline Riparian* & 163 & 50.7 & 418 & 1.77 & 6.7 & 37.5 & 12.5 & 56.3 & 253 \\
\hline Moist* & 198 & 36.6 & 338 & 4.62 & 4.1 & 30 & 20 & 75 & 106 \\
\hline Chaparral* $^{*}$ & 299 & 29.2 & 261 & 4.76 & 0.12 & 24.4 & 54.9 & 62.2 & 66.7 \\
\hline Coastal sage* & 212 & 34.5 & 188 & 7.55 & 0 & 6.06 & 42.45 & 62.2 & 80.7 \\
\hline Alpine* & 442 & 20.9 & 266 & 2.53 & 4.7 & 58.3 & 29.15 & 75 & 27.1 \\
\hline Desert scrub* & 361 & 25.9 & 190 & 2.62 & 0 & 40 & 44 & 80 & 20.9 \\
\hline Desert wash* & 148 & 42.2 & 185 & 3.61 & 0 & 11.8 & 26.45 & 70.6 & 139 \\
\hline Succulents* & 44.6 & 57.5 & 245 & 1.84 & 0 & 0 & 0 & 66.7 & 368 \\
\hline Halophytes* & 158 & 29 & 100 & 2.6 & 0 & 0 & 12.5 & 50 & 25.8 \\
\hline Woodland* & 19.3 & 77.8 & 454 & 1.15 & 0 & 0 & 0 & 50 & 1950 \\
\hline Mountain forest ${ }^{* *}$ & 34.7 & 75.6 & 824 & 1.66 & 20.6 & 22.2 & 23.3 & 18.33 & 3512 \\
\hline Tropical deciduous forest ${ }^{* *}$ & 32.8 & 87.5 & 322 & 1.89 & 0 & 0.16 & 0 & 22.31 & 2811 \\
\hline Los Tuxtlas** & 13.2 & 120.8 & 635 & 1.79 & 0.53 & 0 & 0 & 6.67 & 13768 \\
\hline Tafelberg** & 13.9 & 90.8 & 577 & 1.55 & 0.24 & 0 & 8 & 4 & 6913 \\
\hline Porto Velho** & 13.6 & 104.6 & 477 & 1.56 & 0 & 0 & 4 & 0 & 8127 \\
\hline Manaus** & 9.5 & 107.5 & 540 & 1.65 & 1.2 & 0 & 0 & 6 & 12355 \\
\hline El Cien** & 16.24 & 126.7 & 313 & 1.49 & 0 & 0 & 0 & 18.18 & 5948 \\
\hline $\begin{array}{l}\text { Tropical semi-deciduous } \\
\text { forest }^{\star \star *}\end{array}$ & 11.6 & 143.7 & 345 & 1.65 & 0.01 & 0.29 & 0 & 0 & 4269 \\
\hline Xeric shrubland ${ }^{* * *}$ & 37.1 & 101.6 & 340 & 2.56 & 0 & 0.8 & 0 & 0 & 932 \\
\hline Tehuacán Formation & 10.5 & 171.3 & 344 & 1.74 & 0 & 0 & 0 & 19.9 & 6451 \\
\hline
\end{tabular}

acán Formation with other mesic communities and Southern California ecological categories was assessed by comparing nine tracheal characteristics: vessel per square millimeter $\left(\mathrm{Vmm}^{2}\right)$, mean vessel diameter (VD), mean vessel length (VL), mean vessel grouping (VG), mean number of bars per perforation plate (BAR), tracheid proportion (T), proportion of helical sculpture (latewood+earlywood proportion), growth rings (GR), and mesomorphy index (Meso) (Table 2, Carlquist and Hoekman, 1985). For this comparison we made a data matrix that includes nine tracheal characteristics of the paleoflora of the Tehuacán Fm., Martínez-Cabrera and Cevallos-Ferriz (2008) data that includes another Mexican paleoflora (EI Cien), three Mexican extant communities: tropical deciduous forest (Chamela, Jalisco), Los Tuxltas (tropical rain forest in Veracruz), Mountain Forest (Ocuilán, Mexico), and three South American extant wet tropical communities: Porto Vehlo and Manaus (Brazil), and Tafelberg (Suriname). Data compiled by Castañeda-Posadas (2007) from two Mexican communities: a semi-deciduous tropical forest (Champeche state) and a xeric shrubland (Puebla state) were also included. Finally, it includes 10 ecological categories of Southern California: Riparian, Moist, Chaparral, Coastal sage, Alpine, Desert scrub, Desert wash, Succulents, Halophtes, and Woodland based on Carlquist and Hoekman (1985). The anatomical data for each of the communities, paleofloras, and ecological categories can be seen in Table 4. Cluster Analysis and a PCA were carried out, following the same statistical parameters of the previous analysis (physiognomic comparison).

\section{RESULTS}

\section{Climate Inferences}

The climatic variables obtained through the equations of the statistical model proposed by Martínez-Cabrera and Cevallos-Ferriz (2008) are shown in Table 3. All the equations proposed for each variable were included, so that more than one estimation per variable may appear in the table. 
From the estimates obtained by the equations, it is observed that the Annual Average Temperature in the area where the paleoflora of the Tehuacán Formation grew ranged between $24.6{ }^{\circ} \mathrm{C}$ and $25.2{ }^{\circ} \mathrm{C}$, with an average of $25.05^{\circ} \mathrm{C}$ (taking into account the three estimates). Regarding the mean annual range of temperature, the temperature variation was very short $\left(4.6-5.5^{\circ} \mathrm{C}\right)$ with an average of $5.05{ }^{\circ} \mathrm{C}$ (taking into account the two estimates). Evaporation is estimated to be very high, $936.7 \mathrm{~mm}$ throughout the year (MAPE), with a potential evaporation range under $78.4 \mathrm{~mm}$ (MARPE).These two characteristics, together with the minimum $(42.51 \mathrm{~mm})$ and maximum (169.9 $\mathrm{mm}$ ) potential evaporation, suggest that the humidity in the locality was very high.

\section{Physiognomic Comparison}

It is interesting to observe that the Tehuacán Formation appears with a physiognomy similar to that of tropical communities (Figure 3). If the distance values between the paleoflora and the rest of the communities are observed, the distance between them is very similar (Table 5), with the exception of Mountain forest, which has a very large distance. Although the specific physiognomic affinity of the paleoflora is not resolved in the dendogram, El Cien, the tropical semi-deciduous forest, xeric shrubland, and especially the tropical deciduous forest are the communities with the least distance from the Tehuacán Fm. paleoflora (Table 5), suggesting that they have more similar physiognomy, although they are not related within the dendogram.

The apparently isolated relationship of the paleoflora of the Tehuacán Fm. suggests that tropical communities have an anatomical physiognomy much more similar to each other than to the paleoflora. That is, the distance values that exist between tropical communities are shorter than the distance values they have with the Tehuacán Fm. paleoflora. This suggests that although they share many morpho-anatomic aspects, there are differences that make the paleoflora under study distinctive.

The strong relationship of the paleoflora with tropical communities is also supported by the PCA analysis, which explains $66.47 \%$ of the variation in the first three components and $77.11 \%$ in the first four. This analysis suggests that the tropical deciduous forest, tropical semi-deciduous forest, EI Cien, and Xeric shrubland are closer to the paleo-

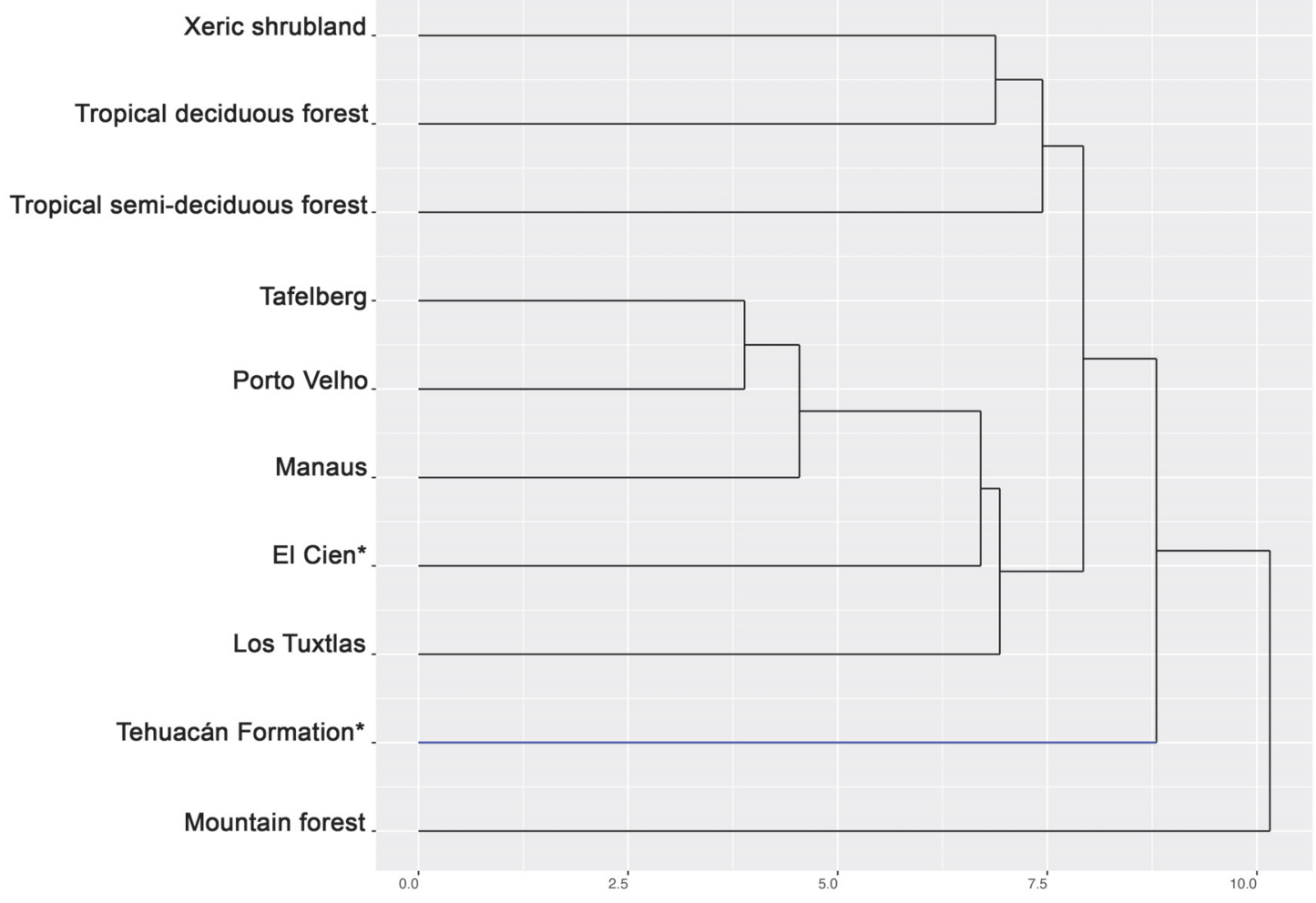

FIGURE 3. Distance dendogram showing the anatomical similarity between extant communities, fossil ones and the Tehuacán Fm. paleoflora. *Fossil paleofloras. 
TABLE 5. Euclidean distance values of the paleoflora of the Tehuacán Fm. compared with the rest of the communities.

\begin{tabular}{lc}
\hline \multicolumn{1}{c}{ Communities } & $\begin{array}{c}\text { Tehuacán } \\
\text { Formation }\end{array}$ \\
\hline Tropical deciduous forest & 7.91 \\
Los Tuxtlas & 9.31 \\
Portovelho & 8.79 \\
Tafelberg & 9.84 \\
Manaus & 9.49 \\
Mountain forest & 12.33 \\
Tropical semi-deciduous forest & 8.41 \\
Xeric shrubland & 8.48 \\
El Cien & 8.14 \\
\hline
\end{tabular}

flora of the Tehuacán Fm. (Figure 4). This grouping is similar to that obtained by the distance analysis since in the PCA the paleoflora appears close to almost all the communities with lowest distance values (with the exception of El Cien).

The communities taken into account in this work are projected within the PCA by the contribution of each of the 34 considered characters (Figure 5). In the PCA analysis, the contribution of each character is given by the variation that exists between the communities and paleofloras studied. The more variation a character has, its contribution will be greater while less variation suggests less contribution. For this reason, in Figure 5, the colors that go from red to blue represent the degree of contribution of the characters: the greater the variation they have, the closer they are to the red color, and as less variation is documented they will tend to have a blue color. In addition to the above and considering that the PCA is a dimensional representation of the variation of the characters, the characters will appear represented with arrows representing towards which component they have greatest contribution (in this case the first or the second components). Thus, the variation of the characters in each community will determine their position in the graph (Figure 4) and their contribution to the analysis.

The communities with which the Tehuacán Fm. paleoflora is related (tropical deciduous forest, tropical semi-deciduous forest, El Cien, and Xeric shrubland), share similarities in a specific group of characters that had different degrees of contribution within the first component (Figure 5). Among the 34 characters taken into account, the charac-

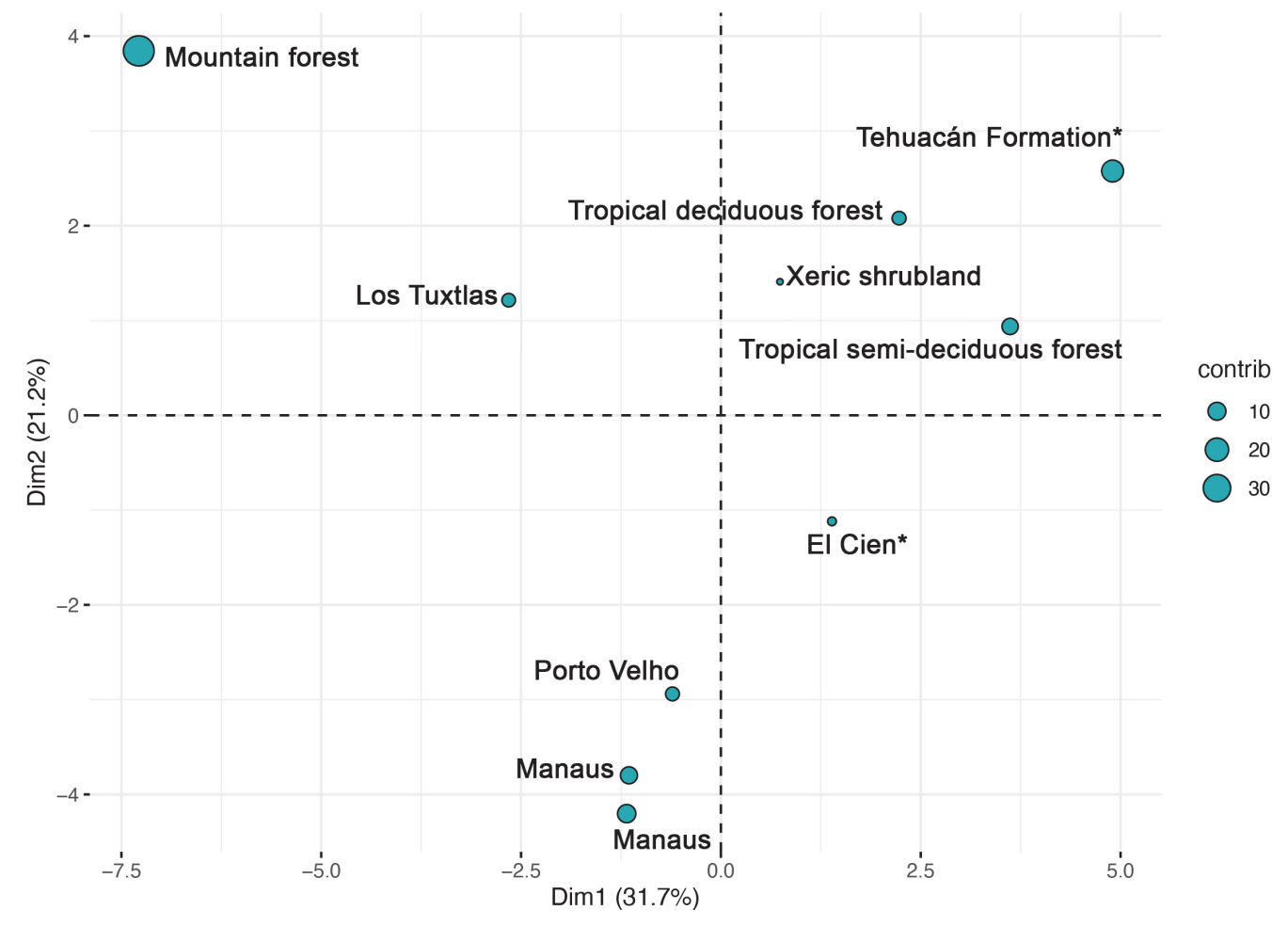

FIGURE 4. Projection of the first two principal components displaying the contribution (contrib) and spatial position of each community within the PCA. 


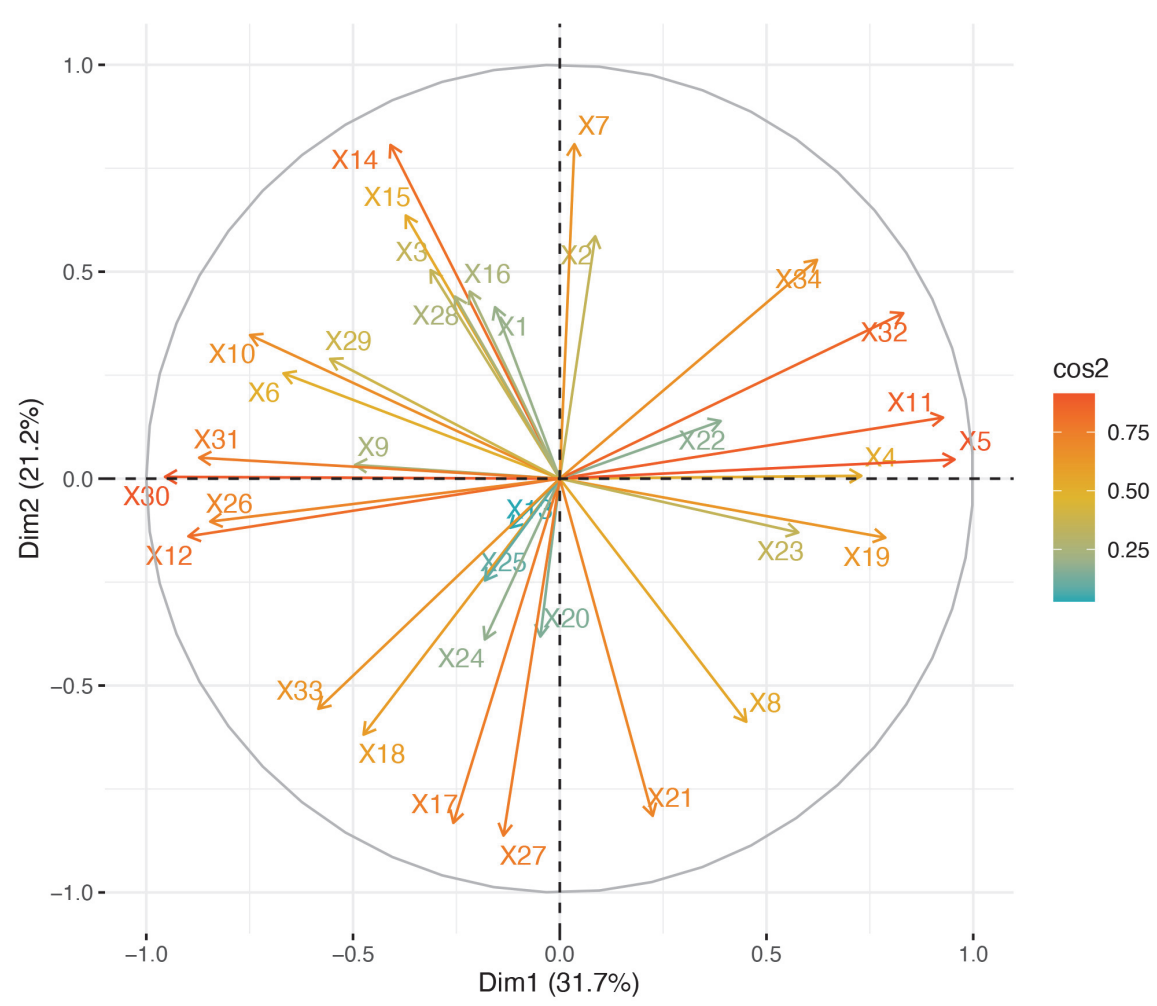

FIGURE 5. Projection of the first two principal components displaying the contribution (cos2) of each anatomical character. (X1) Growth rings, (X2) Vessel grouping, (X3) Vessel frequency, (X4) Vessel diameter, (X5) Vessel wall thickness, (X6) Helical sculpture, (X7) Intervascular pit aperture diameter, (X8) Alternate intervessel pits, (X9) Opposite intervessel pits, (X10) Scalariform intervessel pits, (X11) Simple perforation plates, (X12) Scalariform perforation plates, (X13) Fibre Wall thickness, (X14) Fibre lumen diameter, (X15) Tracheids, (X16) Fibrotracheids, (X17) Libriform fibres, (X18) Parenchyma diffuse in aggregates, (X19) Vasicentric parenchyma, (X20) Aliform parenchyma, (X21) Apotracheal parenchyma bands, (X22) Concentric parenchyma bands, (X23) Marginal parenchyma, (X24) Height of uniseriate ray $(\mu \mathrm{m}),(\mathrm{X} 25)$ Height of uniseriate ray ( $\mathrm{N}^{\circ}$ cells), (X26) Percentage of uniseriate rays, (X27) Exclusively uniseriate rays, (X28) Width of multiseriate ray $(\mu \mathrm{m}),(\mathrm{X} 29)$ Width of multiseriate ray ( $\mathrm{N}^{\circ}$ cells), (X30) Length of uniseriate extensions $(\mu \mathrm{m}),(\mathrm{X} 31)$ Length of uniseriate extensions ( $N^{\circ}$ cells), (X32) Storied structure, (X33) Heterocellular rays, (X34) Homocellular rays.

ters that grouped the communities with the Tehuacán Fm. ordered from lowest to highest contribution are: concentric parecnchyma bands (X22), marginal parenchyma (X23), vessel diameter (X4), vasicentric parenchyma (X19), homocellular rays (X34), storied structure (X32), simple perforation plates (X11), and vessel wall thicknes (X5) (Figure 5).

Within the group of communities with which the paleoflora of Tehuacan Fm. has similarity (tropical deciduous forest, tropical semi-deciduous forest, El Cien, and Xeric shrubland), it stands somewhat separated from them in the data projection of Figure 4, because the paleoflora has the highest contribution value (it has a greater variation of its characters with respect to the other communities). This contribution value contrasts to the rest of the communities and gives a quantitative assess- ment of is distinction from the rest of the group. The anatomical characters that stand out in the paleoflora of the Tehuacán Fm. are the proportion of parenchyma bands (0.785), proportion of marginal parenchyma $(0.142)$, diameter of vessels $(171.3 \mu \mathrm{m})$, marginal parenchyma proportion $(0.857)$, proportion of homocellular rays $(0.357)$, and stratification proportion (0.42). This set of characters is responsible for the paleoflora appearing distant, and it is worth mentioning that they are part of the characters that define the group with which the paleoflora is related and at the same time are the ones with the greatest contribution. In fact, of all the communities studied, the paleoflora has the highest proportion of parenchyma bands, one of the highest proportions of marginal parenchyma (moutain forest has the highest), it has the vessels with the largest diameter, the highest proportion of 


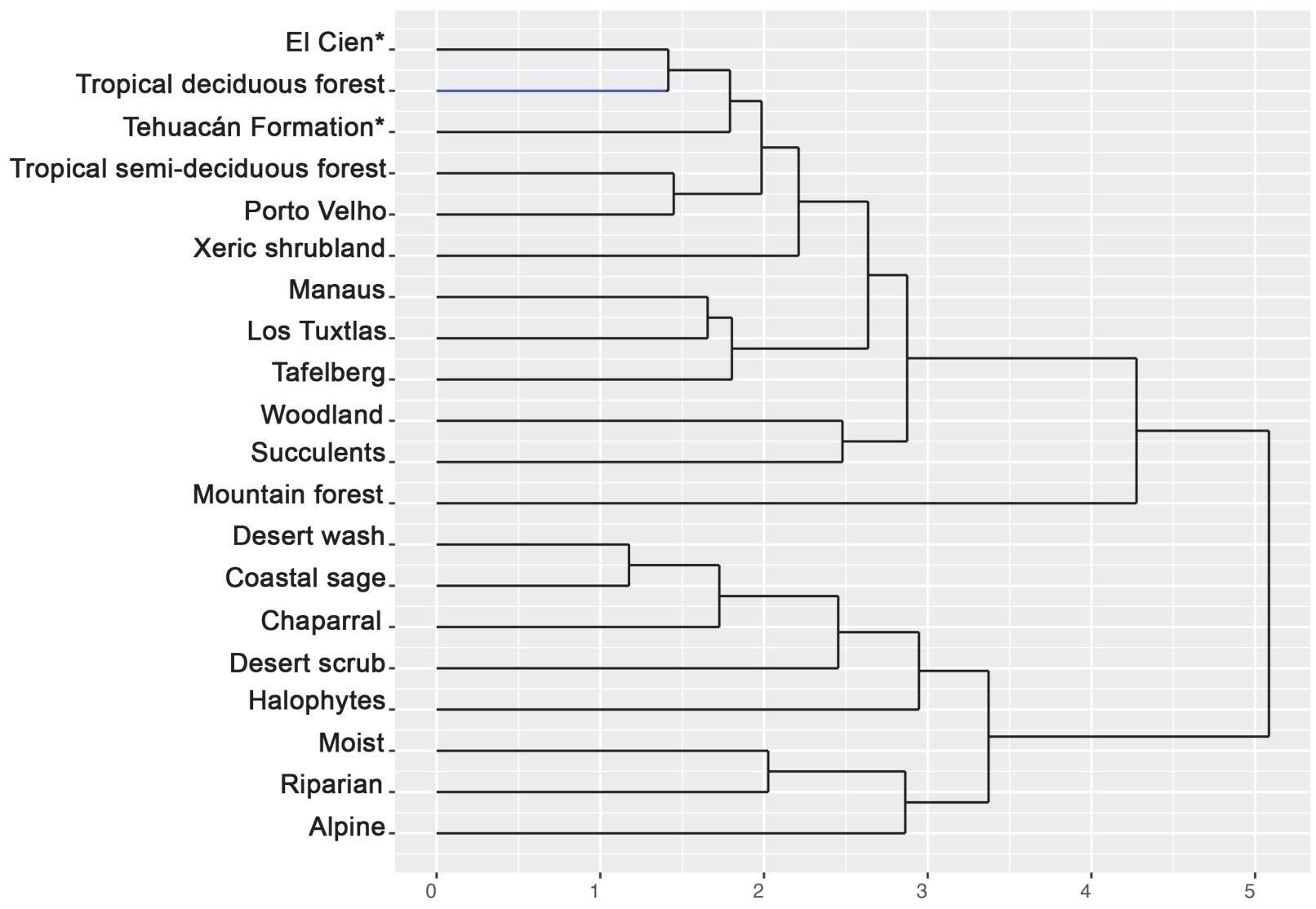

FIGURE 6. Distance dendogram displaying the comparison of the tracheal elements of the Tehuacán Fm. paleoflora with extant communities, fossil ones and Southern California ecological categories in the tracheal elements comparison. *Fossil paleofloras.

marginal parenchyma, high proportion of homocellular rays (it is the third highest), and highest proportion of storied structure.

\section{Tracheal Elements Comparison}

The physiognomic and tracheal comparison of the Tehuacán Fm. paleoflora are concordant and suggest that the paleoflora anatomical characteristics are similar to those found in tropical communities.

In the distance dendrogram (Figure 6) the paleoflora of the Tehuacán Fm. appears in a large cluster composed of only tropical communities. Within this large cluster, the paleoflora of the Tehuacán Fm. is part of a smaller cluster composed of all communities that have a relatively low Euclidean distance value and are characterized by dry and seasonal climatic characteristics. This cluster is made up of El Cien, tropical semi-deciduous forest, tropical deciduous forest, Porto Velho, and xeric shrubland, arranged from highest to lowest resemblance. Within this group, the El Cien and the tropical semi-deciduous have the smallest distance value of all the communities (Table 6). However, the paleoflora of Tehuacán does not appear directly related to these communities because their tracheal characteristics are much more similar between them than with those of the paleoflora under study.

It is possible to observe that tropical communities with tracheal characteristics less similar to those of the Tehuacán flora, form a small cluster with communities growing under more stable and humid climatic characteristics (Manaus, Los Tuxltas, Tafelberg; Figure 6). The Southern California ecological categories used as comparatives in this study are not tropical and grow under different climatic characteristics, for which they form a differentiated group in the distance analysis (Figure 6).

The PCA, which explains $89.34 \%$ of the variation in the first three components, further suggests that the paleoflora is related to tropical communi- 
TABLE 6. Euclidean distance values of the paleoflora of the Tehuacán Fm. and the rest of the communities and ecological categories.

\begin{tabular}{lc}
\hline \multicolumn{1}{c}{ Communities } & $\begin{array}{c}\text { Tehuacán } \\
\text { Formation }\end{array}$ \\
\hline Riparian & 4.62 \\
Moist & 5.34 \\
Chaparral & 5.94 \\
Coastal sage & 5.45 \\
Alpine & 7.24 \\
Desert scrub & 6.59 \\
Desert wash & 4.70 \\
Succulents & 2.94 \\
Halophytes & 4.94 \\
Woodland & 2.78 \\
Mountain forest & 4.92 \\
Tropical deciduous forest & 2.14 \\
Los Tuxtlas & 2.71 \\
Tafelberg & 2.60 \\
Porto Velho & 2.28 \\
Manaus & 2.66 \\
El Cien & 1.44 \\
Tropical semi-deciduous forest & 1.87 \\
Xeric shrubland & 2.81 \\
\hline
\end{tabular}

ties since the variation of the tracheal elements in the first two components places it near the Tropical semi-deciduous forest, Porto Velho, the paleoflora of El Cien and Woodland (Figure 7). This result is similar to that observed in the distance analysis. Like the physiognomic comparison, the variation of the characters through the communities and the Southern California ecological categories will determine their contribution and their position in the graph through the first two main components.

The contribution value of the characters that explained relationships of the paleoflora of Tehuacán Fm. in the PCA has a tendency to group communities and ecological categories in the first component (Figure 8). The involved characters in the first principal component (Figure 8) are vessels per square millimeter $\left(\mathrm{Vmm}^{2}\right)$, proportion of helical sculpture (SE), mesomorphy index (MESO), and mean vessel diameter (VD). Other important characters influencing this relationship appear with high contribution values only in the second principal component (Figure 8) and include mean vessel length (VL), tracheid proportion ( $T$ ), and mean number of bars per perforation plate (BAR). The contribution of each character (red to blue) is explained in the same way as in the previous sec- tion. According to the distribution of the mentioned characters, towards the negative values in the first principal component, are communities with high values of mesomorphy (as suggested by presence of wide vessels and low proportion of vessels per $\mathrm{mm}^{2}$ ) are typical of all tropical forests considered in this study. The paleoflora of the Tehuacán Fm. appears within the group mentioned above with a high mesomorphy (6451), wide vessel elements $(171.3 \mu \mathrm{m})$, and a low proportion of vessels per $\mathrm{mm}^{2}$ (10.5 vessels per $\mathrm{mm}^{2}$ ) (Figure 7).

Analyzing the first and second components together, the combination of both components produces a more selective separation of some communities. Towards the positive values of the second main component and towards the negative values of the first principal component where the tropical forests are grouped, communities with low proportion or absence of bars in the perforation plates (BAR) and wider vessel elements, but of short length are located (Tehuacán Formation, tropical semi-deciduous forest, Porto Velho, El Cien, and Woodland; Figure 7). Within this group the paleoflora of the Tehuacán Fm. has the widest $(171.3 \mu \mathrm{m})$ and shortest vessels $(344 \mu \mathrm{m})$. On the other hand, towards the negative values of the second principal component and the negative values of the first principal component, the tropical forests with vessel elements with larger diameter (VD) and greater length $(\mathrm{VL})$ as well as higher proportion of bars in perforation plates (BAR), are represented by communities of Manaus, Tafalberg, and Los Tuxtlas (Figure 7).

Towards the positive values of the first component, the ecological communities of Southern California appear (Succulents, Riparian, Halophytes, Desert wash, Moist, Coastal sage, Chaparral, Desert scrub, and Alpine; Figure 7) since they have lower mesomorphy indices, small diameter vessels $(>60 \mu \mathrm{m})$, and a higher frequency of vessels per square millimeter ( $>50$ vessels per square millimeter). Their distribution within the second main component respond to the proportion of tracheids $(\mathrm{T})$ and the proportion of bars in the perforation plates (BAR). Their distribution on the left side of the graph (Figure 7) suggests that the climatic conditions under which they develop are different from those that occur in tropical communities where the paleoflora of the Tehuacán Fm. is located.

\section{DISCUSSION}

The effort to elucidate the origin and evolution of the vegetation of Mexico through the fossil record is reinforced by the climatic analysis based 


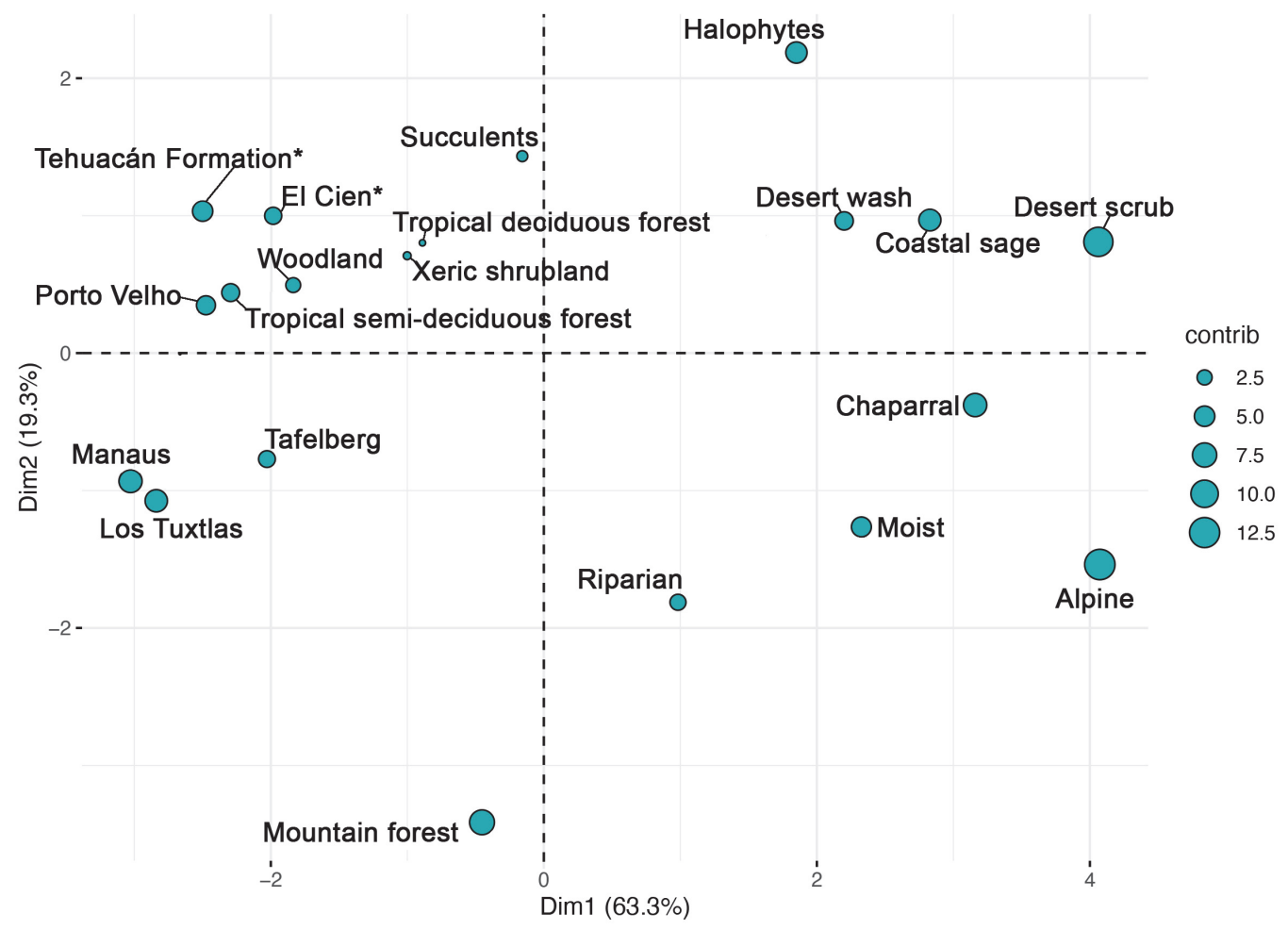

FIGURE 7. Projection of the first two principal components that displays the contribution (contrib) and spatial position of each communities within the PCA.

on fossil woods and leaves of different localities. The focus of this study uses the understanding of the expression and plasticity of certain anatomical characters of wood in relation to climate.

\section{Climatic Conditions}

According to the modification of the Köppen system for Mexico made by Enriqueta García (2004), the climatic conditions here calculated for Upper Oligocene in this part of Mexico were similar to the warm humid climatic group $(A)$. This means that the paleoflora developed under a climate with mean annual temperature higher than $22{ }^{\circ} \mathrm{C}$ and have a low range of temperature, which allows to have minimum temperatures in general above 18 ${ }^{\circ} \mathrm{C}$. Within the warm humid group of García (2004) accurate classification of the paleoclimate of the Tehuacán Fm. is a bit more complicated since the precipitation value is unknown, and this data is important when classifying this type of climate (Kottek et al., 2006). However, evaporation calculated from Tehuacán Fm. paleoflora suggests the existence of warm humid conditions. The values calculated for the mean annual evaporation (MAPE) and the mean annual evaporation interval
(MARPE) are comparable with those of group A climate: Af (hot humid with rains throughout the year), Aw (hot humid with rains in summer), and Am (hot sub-humid with rains in summer). In these climatic groups evaporation is usually determined by factors such as temperature and precipitation patterns throughout the year (García, 2004; Rzedowsky, 2006).

If the evaporation values of the communities taken into account for this work are compared (Table 7), the Tehuacán Fm. is within the range of tropical forests, being more similar to the Mexican forests, based on their higher evaporation values, compared to South American forests that have lower evaporation values. Focusing on the Mexican rainforests, many of the evaporation values of the Tehuacán Fm. (MAPE, MARPE, and Min PE) are similar to those of Los Tuxtlas, however, the Max PE is more similar to the Tropical semi-deciduous forest, but values are slightly higher. This combination of evaporation parameters suggests that the paleoflora of the Tehuacán Fm. had an intermediate evaporation pattern between the humid (Los Tuxltas) and the drier (tropical semi- 


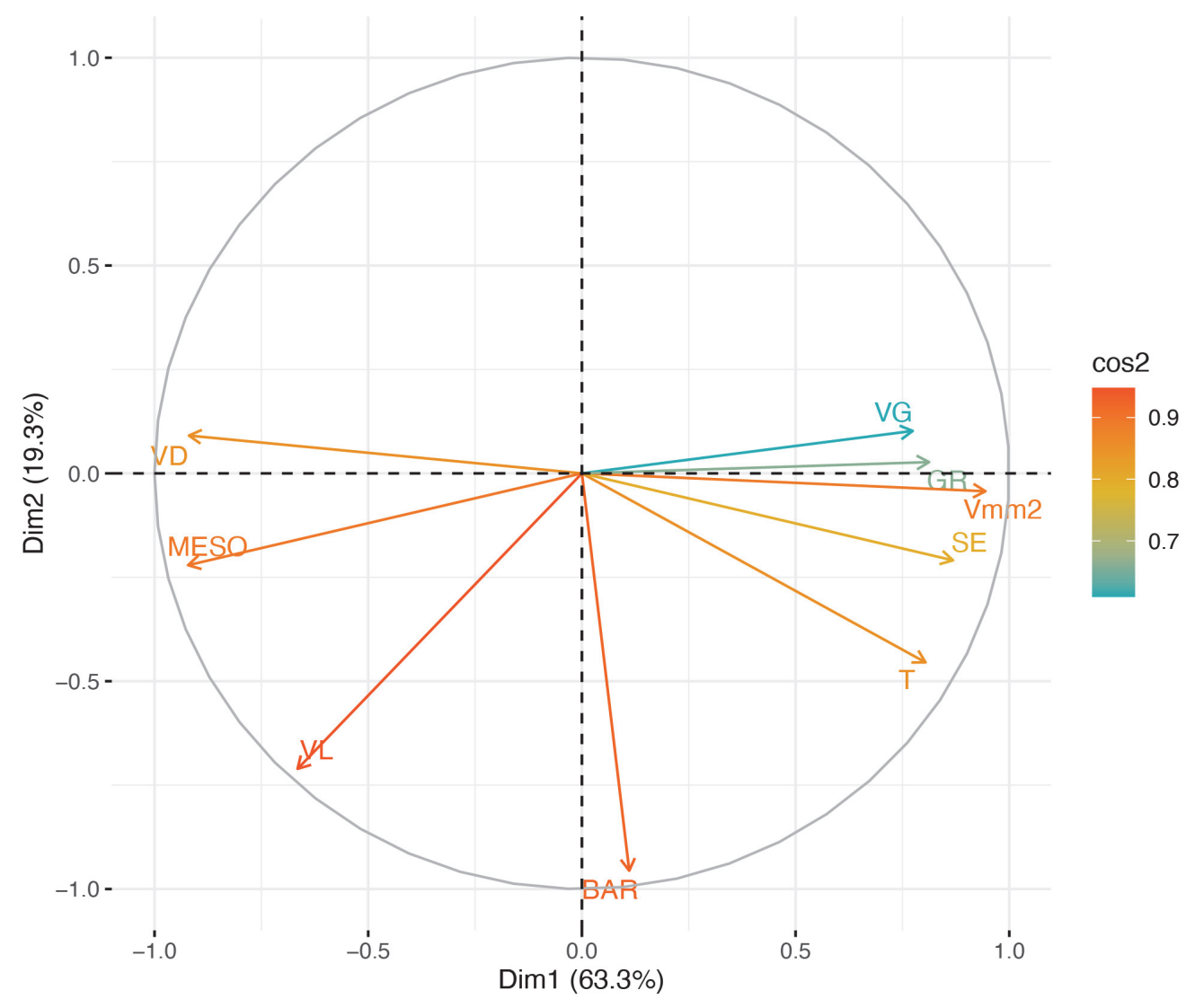

FIGURE 8. Projection of the first two principal components displaying the contribution (cos2) of each tracheal characteristic. $V m^{2}=$ vessels per square millimeter; $V D=$ mean vessel diameter; $V L=$ mean vessel length; $V G=$ mean vessel grouping; $\mathrm{BAR}=$ mean number of bars per perforation plate; $\mathrm{T}=$ tracheid proportion; $\mathrm{SE}=$ proportion of helical sculpture (latewood+early wood proportions); GR= growing rings; MESO= mesomorphy index.

TABLE 7. MAPE, MARPE, Max PE and Min PE data of the communities taken into account in this work. MartínezCabrera and Cevallos-Ferriz, 2008*, Castañeda-Posadas, 2008**.

\begin{tabular}{|c|c|c|c|c|}
\hline Communities & $\begin{array}{c}\text { MAPE } \\
(\mathrm{mm})\end{array}$ & $\begin{array}{c}\text { MARPE } \\
(\mathrm{mm})\end{array}$ & $\begin{array}{c}\text { Max } \\
\text { PE } \\
(\mathrm{mm})\end{array}$ & $\begin{array}{c}\text { Min } \\
\text { PE } \\
\text { (mm) }\end{array}$ \\
\hline Tropical deciduous forest ${ }^{\star}$ & 1322.1 & 185.54 & 202.6 & 17.1 \\
\hline Los Tuxtlas* & 1023.4 & 80.2 & 126.9 & 46.7 \\
\hline Porto Velho* & 793 & 60 & 110 & 50 \\
\hline Manaus* & 812.1 & 60.5 & 102 & 42.2 \\
\hline Mountain forest ${ }^{*}$ & 1400 & 70.3 & 170.3 & 100 \\
\hline Tropical semi-deciduous forest ${ }^{\star \star}$ & 619.6 & 138 & 166 & 28 \\
\hline Xeric shrubland ${ }^{* *}$ & 506 & 29 & 66 & 37 \\
\hline El Cien* & 762.4 & 46.7 & 184.6 & 57 \\
\hline Tehuacan Formation & 936.7 & 78.4 & 169.9 & 42.5 \\
\hline
\end{tabular}


deciduous forest) Mexican forests, the latter with more marked seasonality.

The geological record of the Tehuacán Fm. gives indications about the seasonality that existed in the region. The lithology suggests the existence of seasons of floods and droughts, being marked in the upper part of the formation and moderate towards the base (Dávalos-Alvarez, et al., 2007; Sainz-Reséndiz, 2011; Ramírez-Arriaga et al., 2014). This seasonality has been suggested by the gypsum and evaporite beds intercalated with siltstone that have been interpreted that occurred in the Neogene lakes of central Mexico (DávalosÁlvarez et al., 2007; Sainz-Reséndiz, 2011; Ramírez-Arriaga et al., 2014). The geological information for the base of the formation is important since the presence of moderate periods of flooding and drought are compatible with the proposal of the intermediate pattern between the Mexican forests of Los Tuxtlas (more humid) and the tropical semi-deciduous forest (drier).

\section{The Paleoflora of the Tehuacán Fm. is Similar to Tropical Communities}

The study of current American tropical communities suggests that the plants that comprise them produce wood with a high proportion of simple perforation plates and a low proportion of spiral thickenings (Carlquist and Hoekman, 1985; Baas and Schweingruber, 1987; Wheeler and Baas, 1991; Alves and Angyalossy-Alfonso, 2000), as in the paleoflora of the Tehuacán Fm. The close similarity in the anatomical features of the fossil woods and those of these extant communities suggest that the Tehuacán fossil flora was comprised of tropical vegetation.

One of the main anatomical features that have traditionally been related to conditions with water availability is the large size of the vessel elements (Carlquist, 1977; Barajas-Morales, 1985). However, other studies have observed that the diameter and density of the vessel elements have a more direct relationship with the height and diameter of the plant (Olson and Rosell, 2012; Anfodillo et al., 2013; Olson et al., 2013, 2014). Olson et al. (2013, 2014) observations can help to interpret the paleoflora of the Tehuacán Fm. They propose that large vessel elements $(100-200 \mu \mathrm{m})$ are generally present in plants with heights between 10 and $50 \mathrm{~m}$. Considering that it is unknown from which part of the plant stem (base or apex) the studied samples come and that the average size of the vessel elements is $171 \mu \mathrm{m}$, it can be suggested that the paleocommunity had a plant component with a height ranging between 10 and $50 \mathrm{~m}$.

Another characteristic that can be inferred is the diameter that the plants that generated the wood could have. Olson et al. $(2013,2014)$ mention that plants with large vessel elements (100-50 $\mu \mathrm{m})$ generally have diameters between approximately 20 and $100 \mathrm{~cm}$. The size of the vessel elements of the woods of the paleoflora of the Tehuacán Fm. (171 $\mu \mathrm{m}$ on average), suggest that the plants could have diameters beyond $100 \mathrm{~cm}$.

One of the features that distinguish Mexican tropical forests is the height of the trees that dominate the upper stratum (Rzendowsky, 2006). According to the previous data and the paleoclimatic interpretation, the height and diameter of the Tehuacán Fm.plants correspond with an evergreen tropical forest (humid climate) or a sub-deciduous tropical forest (drier and seasonal climate), in which the trees reach heights between 15 and 50 m (Rzendowsky, 2006).

In addition to the above features, it is interesting to observe that the paleoflora of the Tehuacán $\mathrm{Fm}$. have another transitional anatomical characteristics between humid tropical and drier communities. As in some current humid tropical communities in Mexico and Brazil (BarajasMorales, 1985; Alves and Angyalossy-Alfonso, 2000), the paleoflora was highly mesomorph suggested by its widest vessel elements $(171.3 \mu \mathrm{m}$ on average), very low abundance of vessel elements (10.5 V/mm2), and low proportion of clustered vessels. Supporting the relationship of this paleoflora with humid tropical communities low incidence of contents in the axial parenchyma can be added (Barajas-Morales, 1985). In contrast, the paleoflora also share characteristics with dry tropical communities with more marked seasonality as suggested by the short vessel elements (344 $\mu \mathrm{m}$ on average) with very wide walls $(9.7 \mu \mathrm{m})$ and growth rings in the wood of only some plants (Barajas-Morales, 1985; Lindorf, 1994, Alves and AngyalossyAlfonso, 2000, 2002). These differences can be interpreted as a physiological strategy for both efficiency and safety (Zimmerman 1982).

For the characteristics described above, the plants of the Tehuacán Fm. have a morpho-anatomic organization adapted for efficient conduction as suggested by their wide vessels (as the in humid tropical communites), but at the same time, characteristics of dry communities such as small vessels in aggregates and abundant are important in suggesting some type of seasonality. In this way the evidence supports that the woody plants of the 
Tehuacán Fm. were prepared to conduct water efficiently (like mesic environments), but at the same time they were well equipped to minimize embolisms (like dry environments).

The interpretation of the paleoflora of the Tehuacán Fm. as an intermediate tropical community is well supported by the differences found between the fossil community and extant tropical communities. It is important to highlight the physiognomic comparison agree with the comparison of the tracheal elements, this results in the proposal that the paleoflora of the Tehuacán Fm. is similar (but not identical) to the tropical semi-deciduous forest, except for the growth rings, which are more similar to those of the tropical deciduous forest.

The proximity of the Tehuacán Fm. with the paleoflora of El Cien in the statistical analyzes is important both in the combination of its anatomical characteristics and in the climatic inference. Both paleofloras follow a pattern characterized by their high mesomorphy, presence of few, wide, short, thick-walled vessels, growth rings, and absence or very low proportion of tracheids, spiral thickenings, and bars in the perforation plates. Although this pattern is not identical to extant communities, the paleofloras have a pattern similar to the tropical semi-deciduous forest and the tropical deciduous forest (Martínez-Cabrera and Cevallos-Ferriz, 2008), both communities with seasonal tropical climates.

Based on the information provided by the tracheal elements, it should be noted that although these two paleofloras are very similar, the proportion values of the paleoflora of the Tehuacán Fm. are slightly higher (see Table 2 ) and suggest differences between them. Possibly the difference is induced by the continental nature of the vegetation of the Tehuacán Fm., while El Cien community is a coastal vegetation (Martínez-Cabrera et al., 2006; Martínez-Cabrera and Cevallos-Ferriz, 2008). This situation is similar to the current types of vegetation in Mexico. Although one type of vegetation in different geographic areas shares many characteristics, there is not a 1:1 relationship between them and the limits between communities or populations of the same types of vegetation are difficult to define. This has resulted in different authors using different criteria to define vegetation types (e.g., Miranda and Hernández-X, 1963; Gómez-Pompa, 1965; Rzedowsky, 2006).

\section{Some Wood of the Tehuacán Fm. Paleoflora Suggest a Certain Type of Seasonality}

The presence of morphotypes with growth rings in the Tehuacán Fm. suggests a seasonal climate, as happens in current plants that grow under some type of environmental variation (Worbes, 1999; Roig et al., 2005; Martínez-Cabrera and Cevallos-Ferriz, 2008). Fluctuations in the availability of water, changes in the photoperiod, temperature, hormonal gradients, or a combination of these factors are some of the climatic/physiological traits that can vary and give rise to growth rings (Murphy and Lugo, 1986; Fanjul and Barradas, 1987; Alves and Angyalossy-Alfonso, 2000; Condit, et al., 2000). According to Carlquist (1988) classification, growth rings that occur in some wood of the Tehuacán Fm. are characterized by their diffuse porous wood and annual bands of parenchyma, these can be ecologically interpreted as important in seasonal storage of starch used by the plant to start the growing season (Chowdhury and Tandon, 1964; Carlquist, 1988; Marcati, et al., 2006). As expected, in at least some plants of the dry tropics and therefore in the wood of the Tehuacán Fm. growth rings indicate the beginning of the growing season and support to that some of the elements of this paleoflora responded to some seasonal change. Sainz-Reséndiz (2011) described wood from the Tehuacán Fm. with growth rings and affinity to Cordia L., which reinforce the inferences suggested here. These plants are currently distributed in tropical and subtropical regions of the world, having species with growth rings (BarajasMorales, 1981; Marcelo-Peña et al., 2019).

Altogether the anatomical characteristics of the wood of the plants of the paleoflora of the Tehuacán $\mathrm{Fm}$. suggest that they represent a transitional community. The climatic interpretation and the statistical analyzes suggest the paleoflora is intermediate between tropical semi-deciduous forest and tropical deciduous forest communities. This transitional position (climatic and anatomical) is suggested by the combination of contrasting characters like the fact that most characteristics of the vessel elements are similar to the tropical semideciduous forest, but the proportion of plants with growth rings is reminiscent of the tropical deciduous forest. This possibly reflects the evolution of the communities from the humid tropics in the Paleogene to the dry tropics along the Neogene. 


\section{The Paleoflora of Tehuacán Fm. was a Transitional Community}

A current reference that may apply to this paleoflora is represented by the tropical semideciduous forest described as "halfway" between the humid tropical forests and the dry forests (Rzedowsky, 2006). This definition may apply to the paleoflora of the Tehuacán Fm. because both inferred climate and wood anatomical characteristics are "halfway" between these types of vegetation. Accepting the presence of intermediate paleofloras, Martínez-Cabrera and Cevallos-Ferriz (2008), suggested that ca. 30-20 million years ago as the physiography and climate of Mexico became closer to the current conditions vegetation also evolved. In this context, the intermediate or transitional vegetation types are important to understand the development of biodiversity in Mexico and recognizing their increasingly resemblance to today's types of vegetation, supporting the "apparent slow" but constant change in dynamic of plant communities through time.

The geological-paleontological evidences in the Oligocene of Mexico show transitional characteristics not only in the organisms or their ways of association, but also in the regimes of mountain and hydric development, deterioration of the climate, and the appearance of new environments, etc. (Cevallos-Ferriz and Calvillo-Canadell, 2012). The transition period between the Eocene and the Oligocene is marked by the gradual decrease in global temperatures, with decrease in precipitation and the development of seasonal climates. These changes favored the expansion of cold/temperateclimate plant communities into the southern United States and marked the increasingly limited geographic distribution or elimination of tropical species at high latitudes (Frederriksen, 1991; Graham, 1999). As a result of these climatic and ecological changes, the expansion, evolution, and differentiation of the dry tropics can be traced back to tropical floras in low latitude North America (Cevallos-Ferriz and Calvillo-Canadell, 2012). This dynamic panorama that began in the Paleogene and ended in the Neogene, supports that during the OligoceneMiocene, vegetation types related to the tropical types from which they derive were developed, and plants adapted to increasingly xeric conditions were selected, which with the time resulted in the vegetation currently growing in the dry tropics of Mexico.

Other localities were studied from the Oligocene of central Mexico, including those of the Coatzingo (Los Ahuehuetes) and Cuayuca Fms., both in the state of Puebla. The discussion about their floras supports the presence of the typical climate present on dry seasonal tropics and with vegetation similar to that of some dry tropical regions of Mexico (dry forests and chaparrales) (Velasco de León and Cevallos-Ferriz, 2000; Calvillo-Canadell and Cevallos Ferriz, 2007; Ramírez-Arriaga et al., 2008; Méndez-Cárdenas et al., 2014). Furthermore, the paleobotanical information available for the Eocene-Oligocene of Mexico suggests that seasonality and the dry conditions in the tropic of Mexico differentiated in the middle Eocene in Northwestern Mexico (Cevallos-Ferriz and CalvilloCanadell, 2012). All these paleofloras, although resembling current types of vegetation, are different from those known today. In a similar way to the paleofloras of the Tehuacán and El Cien Fms., they contain plants with morpho-anatomical characteristics of the humid and dry tropics, with extinct taxa and others whose distribution has been restricted to biogeographic zones other than Mexico (e.g., Calvillo-Canadell and Cevallos-Ferriz, 2002, 2005; Martínez- Cabrera et al., 2006; Méndez-Cárdenas et al., 2014; Hernández-Damián et al., 2016; Ramírez-Arriaga et al., 2017; Hernández-Damián et al., 2018;). The climatic data calculated are also somewhat ambiguous compared with the conditions that characterize current climates (MartínezCabrera and Cevallos-Ferriz, 2008; Domínguez de la Torre, 2013), but as a whole they support the transition of climatic conditions and vegetation of the humid tropics to those of the dry tropics. This historical situation supports the presence of a transitional tropical forests especially in the Neogene. However, in order to observe the true spatial and temporal distribution of this type of vegetation type, it is necessary to study a greater number of paleofloras belonging to these geologic times.

\section{CONCLUSIONS}

The study of the relationship between plants and climate, specifically the relationship that exists between climate and the expression of anatomical features of wood, is important for paleobotany since, together with geology and palynology, they comprehensively reconstruct the environments under which angiosperms have developed over time. Although the use of models based on anatomical characters of the wood have been little used, they represent a good option for paleoclimatic reconstruction since, together with the leaves, they are the most abundant plant organs in the fossil record. 
The paleoclimatic study of the paleoflora of the Tehuacán Fm., made from anatomical characters of the wood, adds to the effort to understand the origin, evolution, and establishment of the extant vegetation of Mexico. In addition, with the rest of the interpretations made for the Oligocene of the state of Puebla, it can be observed that the central part of the country was undergoing a process of climatic and ecological transition, so the conditions of the Tehuacán Valley were not the same during the Oligocene-Miocene than at present: the paleoclimatic estimation model and statistical analyzes demonstrate that the paleoflora of the Tehuacán Fm. grew under a climate of transition.

Finally, the study of the paleoflora of the Tehuacán Fm., together with other Oligocene paleocommunities studied, suggest that by the Oligocene, vegetation types were adapted to sea- sonality. It is interesting to observe that from the Eocene onwards, the paleocommunities of Mexico are composed of a mixture of the humid and the dry tropics plants. The paleoflora of the Tehuacán $\mathrm{Fm}$. is therefore interpreted to represent a transitional stage between the humid and the dry tropics, and certainly is an example of the long process of evolution, differentiation and expansion of the Mexican tropical forests.

\section{ACKNOWLEDGMENTS}

We acknowledge support from PAPIIT-UNAM proyect IN 210416 and Consejo Nacional de Ciencia y Tecnología (Conacyt) proyects 221129 and CF61501 and a scholarship (621458) for graduate School to Marco A. Rubalcava Knoth.

\section{REFERENCES}

Alves, E.S. and Angyalossy-Alfonso, V. 2000. Ecological trends in the wood anatomy of some Brazilian species. 1. growth rings and vessels. IAWA Journal, 21:3-30. https://doi.org/10.1163/22941932-90000233

Alves, E.S. and Angyalossy-Alfonso, V. 2002. Ecological trends in the wood anatomy of some Brazilian species. 2. axial parenchyma, rays and fibers. IAWA Journal, 23:391-418. https://doi.org/10.1163/22941932-90000311

Baas, P. and Schweingruber, F.H. 1987. Ecological trends in the wood anatomy of trees, shrubs and climbers from Europe. IAWA Journal, 8:245-274. https://doi.org/10.1163/22941932-90001053

Barajas-Morales, J. 1981. Descriptions and notes on the wood anatomy of Boraginaceae from western Mexico. IAWA Bulletin, 2:61-67. https://doi.org/10.1163/22941932-90000813

Barajas-Morales, J. 1985. Wood structural differences between trees of two tropical forest in México. IAWA Journal, 6:355-364. https://doi.org/10.1163/22941932-90000962

Beraldi-Campesi, H., Cevallos-Ferriz, S.R.S., Centeno-García, E., Arenas-Abad, C., and Fernández, L.P. 2006. Sedimentology and paleoecology o fan Eocene-Oligocene alluviallacustrine arid system, Southern Mexico. Sedimentary Geology, 191:227-254. https://doi.org/10.1016/j.sedgeo.2006.03.018

Calvillo-Canadell, L. and Cevallos-Ferriz, S.R.S. 2002. Bauhcis moranii gen. et sp. nov. (Cercideae, Caesalpinieae) an Oligocene plant from Tepexi de Rodríguez, Puebla, Mex., with leaf architecture similar to Bauhinia and Cercis. Review of Palaeobotany and Palynology, 122:171-184. https://doi.org/10.1016/s0034-6667(02)00135-5

Calvillo-Canadell, L. and Cevallos-Ferriz, S.R.S., 2005. Diverse assemblage of Eocene and Oligocene Leguminosae from Mexico. International Journal of Plant Science, 166:671-692.

Calvillo-Canadell, L. and Cevallos-Ferriz, S.R.S. 2007. Reproductive structures of Rhamnaceae from the Cerro del Pueblo (late Cretaceous, Coahuila) and Coatzingo (Oligocene, Puebla) Formations, Mexico. American Journal of Botany, 94:1658-1669. https://doi.org/10.3732/ajb.94.10.1658

Carlquist, S. 1977. Ecological factors in wood evolution: a floristic approach. American Journal of Botany, 64:887-896. https://doi.org/10.1002/j.1537-2197.1977.tb11932.x

Carlquist, S. and Hoekman D.A. 1985. Ecological wood anatomy of the woody Southern California flora. IAWA Journal, 6:319-344. https://doi.org/10.1163/22941932-90000960

Carlquist, S. 1988. Comparative Wood Anatomy. Systematic, Ecological and Evolutionary Aspects of Dicotyledon Wood. Springer-Verlag. Germany. 
Carlquist, S. 1996. Wood anatomy of Compositae. A summary, with comments on factors controlling wood evolution. Aliso, 6:24-44. https://doi.org/10.5642/aliso.19660602.03

Carlquist, S. 2013. Comparative Wood Anatomy. Systematic, Ecological and Evolutionary Aspects of Dicotyledon Wood. Springer-Verlag. Berlin.

Castañeda-Posadas, C. 2007. Modelo paleoclimático basado en los caracteres anatómicos de la madera de las rocas miocénicas de las regones de Panotla, Talxcala y Chajul, Chiapas. Unpublished Master Thesis, Posgrado en Ciencias Biológicas, Universidad Nacional Autónoma de México, México City, México.

Cevallos-Ferriz, S.R.S. and Calvillo-Canadell, L. 2012. La Historia que Cuentan las Plantas. Dirección General de Publicaciones y Fomento Editorial. México.

Chaloner, G.T. and Creber, G.T. 1990. Do fossil plants give a climatic signal? Journal of Geological Society, 147:343-350. https://doi.org/10.1144/gsjgs.147.2.0343

Chowdhury, A.K. and Tandon, N.K. 1964. A fossil wood of Terminalia tomentosa W. \& A. from the tertiary of Burma. Annals of Botany, 28:445-450. https://doi.org/10.1093/oxfordjournals.aob.a083904

Condit, R., Watts, K., Bohlman, S., Pérez, R., Foster, R., and Hubbell, S.P. 2000. Quantifying the deciduousness of tropical forest canopies under varying climates. Journal of Vegetation Science, 11:649-658. https://doi.org/10.2307/3236572

Dávalos-Álvarez, O.G., Nieto-Samaniego, A.F., Alaniz-Álvarez, S.A., Martínez-Hernández, E., and Ramírez-Arriaga, E. 2007. Estratigrafía cenozoica de la región de Tehuacán y su relación con el sector norte de la falla de Oaxaca. Revista Mexicana de Ciencias Geológicas, 2:197-215.

Domínguez-de la Torre, A. 2013. Reconstrucción paleoclimática con base en la diversidad foliar del Mioceno de San Esteban Tizatlán, Tlaxcala. Unpublished Graduate Thesis, Facultad de Ciencias, UNAM, México City, México.

Fanjul, L. and Barradas, V.L. 1987. Diurnal and seasonal variation in the water relations of some deciduous and evergreen trees of a deciduous dry forest of the Eastern Coast of Mexico. Journal of Applied Ecology, 24:298-303. https://doi.org/10.2307/2403805

Ferrari, L., Conticelli, S., Vaggelli, G., Petrone, M.C., and Manetti, P. 2000. Late Miocene volcanism and intra-arc tectonics during the early development of the Trans-Mexican Volcanic Belt, Tectonophysics. 318:161-185. https://doi.org/10.1016/s0040-1951(99)00310-8

Frederiksen, O. 1991. Pulses of middle Eocene to earliest Oligocene climatic deterioration in Southern California and the Gulf Coast. PALAIOS. 6:564-571. https://doi.org/10.2307/3514919

García, E. 2004. Modificaciones al Sistema de Clasificación Climática de Köppen. Universidad Nacional Autónoma de México, México.

Gómez-Pompa, A. 1965. La vegetación de México. Botanical Sciences, 29:76-120. https://doi.org/10.17129/botsci.1090

Gómez-Tuena, A., Orozco-Esquivel, M.T., and Ferrari, L. 2007. Igneous petrogenesis of the Trans-Mexican Volcanic Belt. Geological Society of America Special Papers, 422:129-181. https://doi.org/10.1130/2007.2422(05)

Graham, A. 1999. Late Cretaceous and Cenozoic History of North America Vegetation. Oxford University Press, New York, USA.

Haas, H. and Rowe, N.P. 1999. Thin sections and wafering, p. 76-81. In Jones T.P. and Rowe, N.P. (eds.), Fossil Plants and Spores: Modern Techniques. Geological Society of London, London.

Hernández-Damián, A., Calvillo-Canadell, L., and Cevallos-Ferriz, S.R.S., Sousa, M. 2016. Miocene Lonchocarpus (Papilionoideae) in San Esteban Tizatlán, Tlaxcala, México. Journal of South American Earth Sciences, 66:73-81. https://doi.org/10.1016/j.jsames.2015.12.004

Hernández-Damián A., Gómez-Acevedo, S.L., and Cevallos-Ferriz, S.R.S. 2018. Fossil flower of Salacia lombardii sp. nov. (Salacioideae-Celastraceae) preserved in amber from Simojovel de Allende, Mexico. Review of Paleobotany and Palynology, 252:1-9. https://doi.org/10.1016/j.revpalbo.2018.02.003

Jud, N.A., Wheeler, E.A., Rothwell, G.W., and Stockey, R.A. 2017. Angiosperm wood from the Upper Cretaceous (Conician) of British Columbia, Canada. IAWA Journal, 38:141-161. https://doi.org/10.1163/22941932-20170164

Kottek, M., Grieser, J., Beck, C., Rudolf, B., and Rubel, F. 2006. World map of the KöppenGeiger climate classification updated. Meteorologische Zeitschrift, 3:259-263. https://doi.org/10.1127/0941-2948/2006/0130 
Lindorf, H. 1994. Eco-anatomical wood features of species from a very dry tropical forest. IAWA Journal, 15:361-376. https://doi.org/10.1163/22941932-90001370

Magallón-Puebla, S. and Cevallos-Ferriz, S.R.S. 1993. A fossil earthstar (Geasteraceae; Gasteromycetes) from the late Cenozoic Pie de Vaca Formation, Puebla, Mexico. American Journal of Botany, 80:1162-1167. https://doi.org/10.1002/j.1537-2197.1993.tb15348.x

Marcati, C.R., Angyalossy, V., and Evert., F.R. 2006. Seasonal variation in wood formation of Cedrela fissilis (Meliaceae). IAWA Journal, 27:199-211. https://doi.org/10.1163/22941932-90000149

Marcelo-Peña, J.L., Santini, L., and Tomazello-Filho, M. 2019. Wood anatomy and growth rate of seasonally dry tropical forest trees in the Marañón River Valley northern Peru. Dendrochronologia, 55:135-145. https://doi.org/10.1016/j.dendro.2019.04.008

Martínez-Cabrera, H.I., Cevallos-Ferriz, S.R.S., and Poole, I. 2006. Fossil woods from early Miocene sediments of the El Cien Formation, Baja California Sur, México. Review of Palaeobotany and Palynology, 138:141-163. https://doi.org/10.1016/j.revpalbo.2006.01.001

Martínez-Cabrera, H.I. and Cevallos-Ferriz, S.R.S. 2008. Palaeoecology of the Miocene El Cien Formation (Mexico) determined from wood anatomical characters. Review of Paleobotany and Palynology, 150:154-167. https://doi.org/10.1016/j.revpalbo.2008.01.010

Martínez-Cabrera, H.I. and Estrada-Ruíz, E. 2018. Influence of phylogenetic relatedness on paleoclimate estimation using fossil wood: vessel and fiber-related traits. Review of Palaeobotany and Palynology, 521:73-77. https://doi.org/10.1016/j.revpalbo.2018.01.003

Méndez-Cárdenas, J.P., Cevallos-Ferriz, S.R.S., Calvillo-Canadell, L., Rodríguez-Yam, G.A., Boja, A.M., and Martínez-Cabrera, H.I. 2014. Loxopterygium wood in Coayuca de Andrade, Oligocene of Puebla, Mexico. Review of Palaeobotany and Palynology, 207:38-43. https://doi.org/10.1016/j.revpalbo.2014.04.004

Miranda, F. and Hernández-X, E. 1963. Los tipos de vegetación en México y su clasificación. Botanical Sciences, 28:29-179. https://doi.org/10.17129/botsci.1084

Murphy, P.G. and Lugo, A. E. 1986. Ecology of tropical dry forest. Annual Review of Ecology and Systematics, 17:67-68. https://doi.org/10.1146/annurev.es.17.110186.000435

Olson, M.O. and Rosell, J.A. 2012. Vessel diameter-stem diameter scaling across woody angiosperms and the ecological causes of xylem vessel variation. New Phytologist, 197:1204-1213. https://doi.org/10.1111/nph.12097

Olson, M.E., Rosell J.A., León, C., Zamora, S., Weeks, A., Alvarado-Cárdenas, L.O., Cacho, N.I., and Grant. J. 2013. Convergent vessel diameter - stem diameter scaling across five clades of New and Old World eudicots from desert to rain forest. International Journal of Plant Sciences, 174:1062-1068. https://doi.org/10.1086/671432

Olson, M.E., Anfoldillo, T., Rosell, J.A., Petit, G., Crivellaro, A., Isnard, S., León-Gómez, C., Alvarado-Cárdenas, L. O., and Castorena M. 2014. Universal hydraulics of the flowering plants: vessel diameter scales with stem length across angiosperm lineages, habits and climates. Ecology Letters, 17:988-997. https://doi.org/10.1111/ele.12302

Pérez-García, E., Meave, J.A., and Cevallos-Ferriz, S.R.S. 2012. Flora and vegetation of the seasonally dry tropics in Mexico: Origin and Biogeographical Implications. Acta Botanica Mexicana, 100:149-193.

Poole, I. 2000. Fossil angiosperm wood: its role in the reconstruction of biodiversity and palaeoenvironment. Botanical Journal of the Linnean Society, 134:361-381.

Ramírez-Arriaga, E., Martínez-Hernández, E., Flores-Olvera, H., Ochotorena, H., and Prámparo, M.B. 2008. Correlation of the late Eocene-Early Oligocene Izúcar de Matamoros evaporites (Cuayuca Formation) in Mexico based on parsimony analysis of endemicity. Palynology, 32:231-252. https://doi.org/10.2113/gspalynol.32.1.231

Ramírez-Arriaga, E., Prámparo, M.B., Nieto-Samaniego A.F., Martínez-Hernández, E., ValienteBanuet, A., Macías-Romo, C., and Dávalos Álvarez, O.G. 2014. Palynological evidence for middle Miocene vegetation in the Tehuacán Formation of Puebla, México. Palynology, 38:127. https://doi.org/10.1080/01916122.2013.802750

Ramírez-Arriaga, E., Prámparo, M.B., Nieto-Samaniego A.F., and Valiente-Banuet, A. 2017. Eocene Mequitongo Formation palynoflora from the intertropical Tehuacán-Cuicatlán valley, Mexico. Review of Palaeobotany and Palynology, 246:14-31. https://doi.org/10.1016/j.revpalbo.2017.06.001

Ramírez, J.L. and Cevallos-Ferriz, S.R.S. 2000. Leaves of Salicaceae (Salix and Populus) from Oligocene sediments near Tepexi de Rodríguez, Puebla, Mexico. International Journal of Plant Sciences, 161: 521-534. https://doi.org/10.1086/314260 
Roig, F.A., Osornio, J.J.J., Diaz, J.V., Luckman, B., Tiessen, H., Medina, A., and Noellemeyer, E.J. 2005. Anatomy of growth rings at the Yucatán Peninsula. Dendrochronologia, 22:187193. https://doi.org/10.1016/j.dendro.2005.05.007

Rzedowski, J. 2006. Vegetación de México. First Digital Edition, Comisión Nacional para el Conocimiento y Uso de la Biodiversidad, México. https://www.biodiversidad.gob.mx.

Sainz-Reséndiz, B.A. 2011. Descripción e identificación de maderas del paleógeno de San Juan Atzingo, Puebla, México. Unpublished Graduate Thesis, Facultad de estudios Superiores Iztacala, Universidad Nacional Autónoma de México, México.

Smith, B.V., David, H.C., Cardenas, B.M., and Yang L.Z. 2013. Climate, river network, and vegetation cover relationships across a climate gradient and their potential for predicting effects of decadal-scale climate change. Journal of Hydrology, 488:101-109. https://doi.org/10.1016/j.jhydrol.2013.02.050

Turner, P.D., Cohen, B.W., Kennedy, E.R., Fassnacht, S.K., and Briggs, M.J. 1999. Relationships between leaf area index and Landsat TM spectral vegetation indices across three temperate zones sites. Remote Sensing of Environment, 70:52-68. https://doi.org/10.1016/s0034-4257(99)00057-7

Velasco de León, P. and Cevallos-Ferriz, S.R.S. 2000. Leaves of Cercocarpus mixteca n. sp. (Rosaceae) from Oligocene sediments, near Tepexi de Rodríguez, Puebla. Review of Paleobotany and Palynology, 111:285-294. https://doi.org/10.1016/s0034-6667(00)00029-4

Wheeler, E.A. and Baas, P. 1991. A survey of the fossil record for dicotyledonous wood and its significance for evolutionary and ecological wood anatomy. IAWA Journal, 12:275-318. https://doi.org/10.1163/22941932-90001256

Wheeler, E.A. and Baas, P. 1993. The potentials and limitations of dicotyledonous wood anatomy for climatic reconstructions. Paleobiology, 19:487-498. https://doi.org/10.1017/s009483730001410x

Wiemann, M.C., Wheeler, E.A., Manchester, S.R., and Portier, K.M. 1998. Dicotyledonous wood anatomical characters as predictors of climate. Palaeogeography, Palaeoclimatology, Palaeoecology, 139:83-100. https://doi.org/10.1016/s0031-0182(97)00100-4

Wiemann, M.C., Manchester, S., and Wheeler, E.A. 1999. Palaeotemperature estimation from dicotyledonous wood anatomical characters. PALAIOS, 14:459-474. https://doi.org/10.2307/3515397

Woodcock, D.W. and Ingas, C.M. 1994. Prevalence of wood characters in eastern North America. What characters are most promising for interpreting climates from fossil woods? American Journal of Botany, 81:1243-1251. https://doi.org/10.1002/j.1537-2197.1994.tb11445.x

Worbes, M. 1999. Annual growth rings, rainfall-dependent growth and long-term growth patterns of tropical trees from the Caparo Forest Reserve in Venezuela. Journal of Ecology, 87:391403. https://doi.org/10.1046/j.1365-2745.1999.00361.x

Zimmermann, M.H. 1982. Functional xylem anatomy of angiosperm trees, p. 59-70. In Baas, P. (ed.), New Perspectives in Wood Anatomy. Springer Netherlands, Dordrecht. 


\section{APPENDIX CAPTIONS}

APPENDIX 1. Primary information of the 20 morphotypes recognized in this work (Morpho 1 to Morpho 20) and the information collected from eight morphotypes studied by Sainz-Reséndis (2008) (S.R. Morpho 1 to S.R. Morpho 8). For the morphotypes studied in this work, the 25 different observations are shown for each of the 34 wood anatomy characters strongly related to climatic variables (Martínez-Cabrera and Cevallos-Ferriz, 2008). All appendices are available for download as PDFs at https://palaeo-electronica.org/content/pdfs/1136_appendices.zip.

APPENDIX 2. Average anatomical information of the paleoflora of the Fm. Tehuacán (blue column) from the mean and proportion values of each character for each of the morphotypes (gray). All appendices are available for download as PDFs at https://palaeo-electronica.org/content/ pdfs/1136_appendices.zip.

APPENDIX 3. Data matrix that includes the data generated by Martínez-Cabrera et al., (2008; *), the unpublished data generated by Castañeda-Posadas, $\left(2008 ;{ }^{* *}\right)$ and the data obtained in this work for the paleoflora of the Tehuacán Fm. The characters strongly related to some climatic variable (Martínez-Cabrera et al., 2008) are: (1) Growth rings, (2) Vessel grouping, (3) Vessel frequency, (4) Vessel diameter, (5) Vessel wall thicknes, (6) Helical sculpture, (7) Intervascular pit aperture diameter, (8) Alternate intervessel pits, (9) Opposite intervessel pits, (10) Scalariform intervessel pits, (11) Simple perforation plates, (12) Scalariform perforation plates, (13) Fibre wall thickness, (14) Fibre lumen diameter, (15) Tracheids, (16) Fibrotracheids, (17) Libriform fibres, (18) Parenchyma diffuse in aggregates, (19) Vasicentric parenchyma, (20) Aliform parenchyma, (21) Apotracheal parenchyma bands, (22) Concentric parenchyma bands, (23) Marginal parenchyma, (24) Height of uniseriate ray $\mu \mathrm{m}$, (25) Height of uniseriate ray ( $\mathrm{N}^{\circ}$ cells), (26) Percentage of uniseriate rays, (27) Exclusively uniseriate rays, (28) Width of multiseriate ray $(\mu \mathrm{m}),(29)$ Width of multiseriate ray ( $\mathrm{N}^{\circ}$ cells), (30) Length of uniseriate extensions $(\mu \mathrm{m}),(31)$ Length of uniseriate extensions ( $\mathrm{N}^{\circ}$ cells), (32) Storied structure, (33) Heterocellular rays, (34) Homocellular rays. All appendices are available for download as PDFs at https://palaeo-electronica.org/content/pdfs/ 1136_appendices.zip. 